\title{
Pre- and syn-eruptive degassing and crystallisation processes of the 2010 and 2006 eruptions of Merapi volcano, Indonesia
}

\author{
Katie Preece $\cdot$ Ralf Gertisser $\cdot$ Jenni Barclay $\cdot$ Kim Berlo $\cdot$ \\ Richard A. Herd · Edinburgh Ion Microprobe Facility
}

Received: 30 December 2013 / Accepted: 2 September 2014 / Published online: 1 October 2014

(c) The Author(s) 2014. This article is published with open access at Springerlink.com

\begin{abstract}
The 2010 eruption of Merapi (VEI 4) was the volcano's largest since 1872. In contrast to the prolonged and effusive dome-forming eruptions typical of Merapi's recent activity, the 2010 eruption began explosively, before a new dome was rapidly emplaced. This new dome was subsequently destroyed by explosions, generating pyroclastic density currents (PDCs), predominantly consisting of dark coloured, dense blocks of basaltic andesite dome lava. A shift towards open-vent conditions in the later stages of the eruption culminated in multiple explosions and the generation of PDCs with conspicuous grey scoria and white pumice
\end{abstract}

Communicated by O. Müntener.

Electronic supplementary material The online version of this article (doi:10.1007/s00410-014-1061-z) contains supplementary material, which is available to authorized users.

K. Preece $(\bowtie) \cdot$ J. Barclay $\cdot$ R. A. Herd

School of Environmental Sciences, University of East Anglia,

Norwich NR4 7TJ, UK

e-mail: K.Preece@uea.ac.uk

R. Gertisser

School of Physical and Geographical Sciences, Keele University,

Keele, Staffordshire ST5 5BG, UK

K. Berlo

Department of Earth Sciences, University of Oxford, South Parks

Road, Oxford OX1 3AN, UK

Present Address:

K. Berlo

Department of Earth \& Planetary Sciences, McGill University,

Quebec H3A 2A7, Canada

Edinburgh Ion Microprobe Facility

University of Edinburgh, West Mains Road, Edinburgh EH9 3JW, UK clasts resulting from sub-plinian convective column collapse. This paper presents geochemical data for melt inclusions and their clinopyroxene hosts extracted from dense dome lava, grey scoria and white pumice generated during the peak of the 2010 eruption. These are compared with clinopyroxenehosted melt inclusions from scoriaceous dome fragments from the prolonged dome-forming 2006 eruption, to elucidate any relationship between pre-eruptive degassing and crystallisation processes and eruptive style. Secondary ion mass spectrometry analysis of volatiles $\left(\mathrm{H}_{2} \mathrm{O}, \mathrm{CO}_{2}\right)$ and light lithophile elements $(\mathrm{Li}, \mathrm{B}, \mathrm{Be})$ is augmented by electron microprobe analysis of major elements and volatiles $(\mathrm{Cl}, \mathrm{S}$, F) in melt inclusions and groundmass glass. Geobarometric analysis shows that the clinopyroxene phenocrysts crystallised at depths of up to $20 \mathrm{~km}$, with the greatest calculated depths associated with phenocrysts from the white pumice. Based on their volatile contents, melt inclusions have reequilibrated during shallower storage and/or ascent, at depths of $\sim 0.6-9.7 \mathrm{~km}$, where the Merapi magma system is interpreted to be highly interconnected and not formed of discrete magma reservoirs. Melt inclusions enriched in Li show uniform "buffered" $\mathrm{Cl}$ concentrations, indicating the presence of an exsolved brine phase. Boron-enriched inclusions also support the presence of a brine phase, which helped to stabilise B in the melt. Calculations based on $\mathrm{S}$ concentrations in melt inclusions and groundmass glass require a degassing melt volume of $0.36 \mathrm{~km}^{3}$ in order to produce the mass of $\mathrm{SO}_{2}$ emitted during the 2010 eruption. This volume is approximately an order of magnitude higher than the erupted magma (DRE) volume. The transition between the contrasting eruptive styles in 2010 and 2006 is linked to changes in magmatic flux and changes in degassing style, with the explosive activity in 2010 driven by an influx of deep magma, which overwhelmed the shallower magma system and ascended rapidly, accompanied by closed-system degassing. 
Keywords Merapi $\cdot 2010$ eruption $\cdot 2006$ eruption · Melt inclusions $\cdot$ Volatiles $\cdot$ Degassing

\section{Introduction}

Arc volcanoes may erupt explosively or effusively and transitions between eruptive styles are common. Transitions between effusive dome-forming and explosive (sub) plinian eruptions have been related to changes in various factors, including magma composition, volatile content, degassing regime, changes in magma supply, ascent rate and overpressure, as well as crystallisation during ascent (e.g. Jaupart and Allègre 1991; Woods and Koyaguchi 1994; Eichelberger 1995; Villemant and Boudon 1998; Martel et al. 1998; Melnik and Sparks 1999, 2005; Scandone et al. 2007; Ruprecht and Bachmann 2010). Deep magmatic influx into a reservoir has been identified as an eruption trigger in many previous studies (e.g. Murphy et al. 2000; Ridolfi et al. 2008; Suzuki et al. 2013). Magmatic influx may in turn affect magma ascent dynamics, influencing the rate of magma ascent and whether ascent is sustained or pulsatory in its nature (Wolf and Eichelberger 1997; Scandone et al. 2007). Previous studies have shown that the style of degassing (open vs. closed) is pivotal in determining eruptive behaviour. During open-system degassing, exsolved volatiles are separated and lost from the melt through various pathways such as through the vent and/or the conduit walls, leading to effusive eruptive activity (e.g. Eichelberger et al. 1986; Melnik and Sparks 1999; Villemant et al. 2008). In closed-system degassing, the exsolved volatiles remain within the system, tending to result in increased overpressure, vesicularity and capacity for explosive eruption (Wilson et al. 1980). During magma ascent, processes of degassing and crystallisation, and the consequent changes to magma rheology also influence eruptive style via complex feedback mechanisms (Sparks 1997; Melnik and Sparks 1999, 2005).

Silicate melt inclusions trapped in phenocrysts potentially retain evidence about the pre-eruptive magma that may not be preserved elsewhere, providing critical information about the processes operating during magmatic evolution. For example, melt inclusions can preserve the composition and dissolved volatile concentrations of a pre-eruptive melt, and have previously been used to shed light on minimum pressures of crystallisation and to supply information about exsolved fluids present during crystallisation [see Lowenstern $(1995,2003)$ and Kent (2008) for reviews of the subject]. However, the interpretation of melt inclusion volatile concentrations is challenging, both analytically and due to potential changes in the initial composition by formation of boundary layer conditions (e.g. Baker 2008) or by post-entrapment processes, including crystallisation and diffusive loss through the crystal lattice or cracks (e.g. Lowenstern 1995).

At Merapi, previous volcanological and petrological work suggests that the eruptive style of past dome-forming and larger sub-plinian eruptions has been governed by slow versus fast magma ascent rate and open- versus closed-system degassing (Gertisser 2001; Gertisser et al. 2011) and that shallow-level dynamics control the eruptive behaviour (Gauthier and Condomines 1999). In addition, crustal carbonate assimilation and the resulting $\mathrm{CO}_{2}$ liberation has also been invoked to play a significant role in governing the explosivity of eruptions (Chadwick et al. 2007; Deegan et al. 2010; Troll et al. 2012, 2013; Borisova et al. 2013). Secondary ion mass spectrometry (SIMS) volatile data $\left(\mathrm{CO}_{2}, \mathrm{H}_{2} \mathrm{O}, \mathrm{F}, \mathrm{Cl}, \mathrm{S}\right)$ of Merapi clinopyroxene and amphibole-hosted silicate melt inclusions in lava and scoria from unknown eruptive origins have recently been published by Nadeau et al. (2013). The authors suggest that $\mathrm{CO}_{2}$, liberated by crustal carbonate assimilation fluxed the melt, thereby promoting $\mathrm{CO}_{2}$ enrichment of the melt and $\mathrm{H}_{2} \mathrm{O}$ degassing. In addition, the magmatic volatile phase exsolved into a $\mathrm{H}_{2} \mathrm{O}-\mathrm{Cl}-\mathrm{F}$-rich brine and $\mathrm{CO}_{2}-\mathrm{S}$-rich vapour.

Focussing on the cataclysmic eruption of Merapi in 2010 and the previous eruption in 2006, this paper presents the hitherto most comprehensive set of melt inclusion data, including the first SIMS data for the 2006 and 2010 eruption products. Comparing data between these eruptions is crucial to understand the recent pre-eruptive magmatic system of Merapi. Data include measurements of volatiles $\left(\mathrm{H}_{2} \mathrm{O}, \mathrm{CO}_{2}, \mathrm{Cl}, \mathrm{S}, \mathrm{F}\right)$, light lithophile trace elements $(\mathrm{B}, \mathrm{Li}, \mathrm{Be})$ and major element concentrations in a comprehensive suite of clinopyroxene-hosted melt inclusions, gathered from stratigraphically controlled samples of various stages of the 2010 Merapi eruption. These include dense dome clasts, as well as grey scoria and white pumice, from the subsequent sub-plinian stage (Fig. 1). These data are complemented by analysis of the host clinopyroxene phenocrysts as well as groundmass glass. The diverse and stratigraphically controlled sample set, produced by rapidly changing eruptive behaviour in 2010 , is used to shed light on the magmatic contribution to the shifts in eruptive style during a single eruptive period at Merapi. In addition, comparison of the various 2010 samples to those originating from scoriaceous dome fragments produced during the peak of the dome-forming 2006 eruption, elucidates preeruptive processes during the two most recent and contrasting eruptions of Merapi. Results of this work are beneficial for hazard analysis at Merapi and possibly other domeforming volcanoes worldwide, providing insights into factors contributing to changes in eruptive behaviour, which, as the 2010 eruption of Merapi demonstrated, may occur rapidly and with few imminent warning signs. 


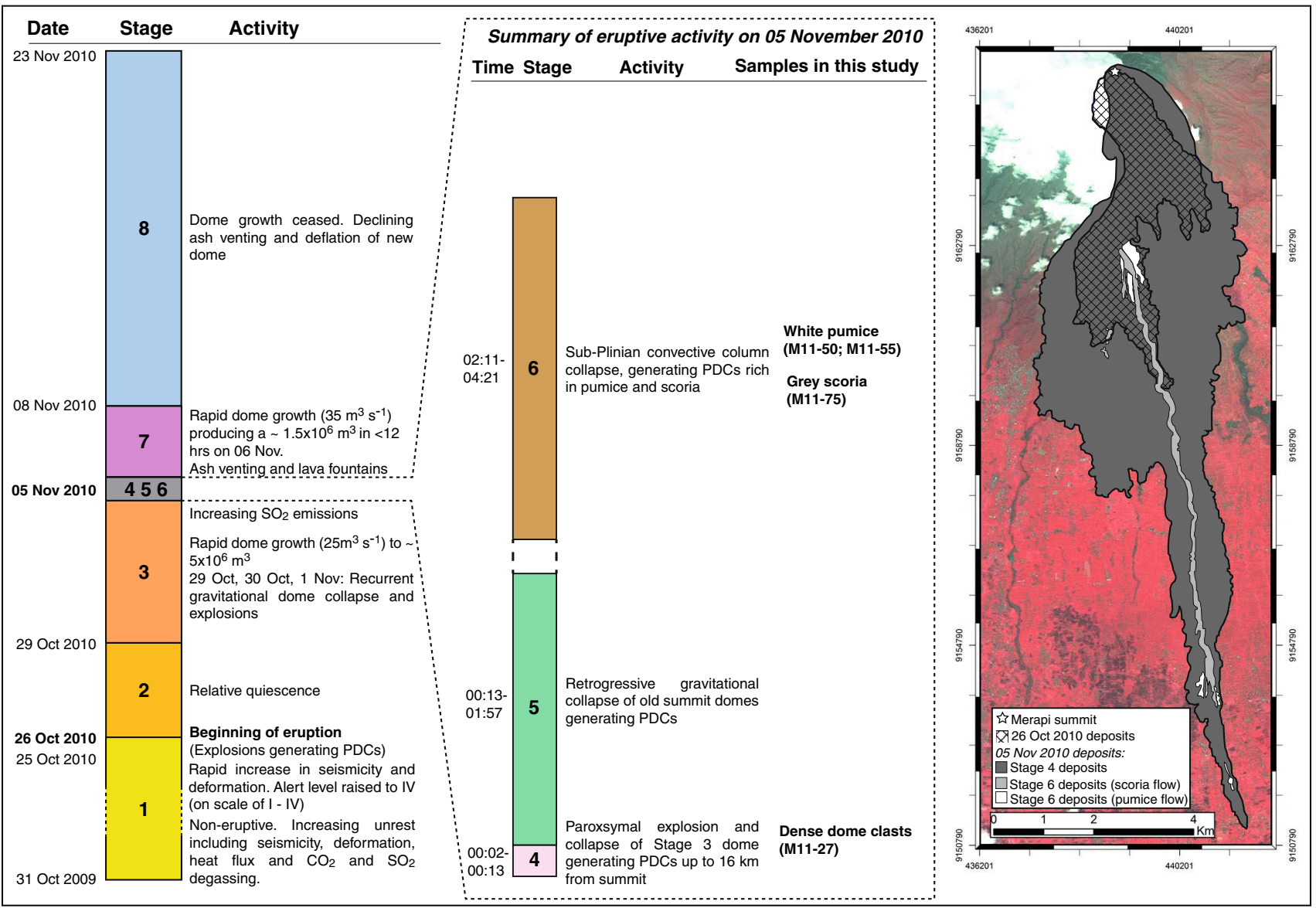

Fig. 1 Eruptive timeline of the 2010 eruption, with stages based on Komorowski et al. (2013) and expanded section describing the paroxysmal eruptive activity of 5 November 2010 and samples used in this

\section{Background}

Merapi magmatic system and volatiles

The plumbing system of Merapi is thought to consist of multiple magma storage and crystallisation regions, ranging over almost the entire thickness of the crust (e.g. Beauducel and Cornet 1999; Ratdomopurbo and Poupinet 2000; Gertisser 2001; Chadwick et al. 2007, 2013; Costa et al. 2013). Evidence for this comes from both petrological and geophysical studies. Geobarometry of magmatic inclusions indicates that crystallisation at Merapi occurs over a wide range of depths $(\sim 2-45 \mathrm{~km})$, with the majority occurring at mid- to lower-crustal levels (12-18 km) (Chadwick et al. 2013). Mineral equilibria in lavas and pyroclastic rocks also reveal a major magma storage region at mid- to lowercrustal levels (14-19 km) (Gertisser 2001), corroborated by estimates of amphibole crystallisation depths (Preece et al. 2011; Nadeau et al. 2013). Petrological data, which elucidate the magma storage conditions prior to the 2006 and 2010 eruptions, demonstrate that there were multiple zones paper. Deposit map showing the extent of deposits emplaced on 26 October 2010, as well as during Stage 4 and Stage 6 (modified after Komorowski et al. 2013)

of crystallisation at depths throughout the crust prior to both eruptions (Costa et al. 2013; Preece et al. 2013; Troll et al. 2013; Preece 2014). Geophysical data also suggest the presence of multiple magma storage regions at Merapi. Tilt and GPS data indicate an average source depth for magma storage at $8.5 \pm 0.4 \mathrm{~km}$ below the summit (Beauducel and Cornet 1999), broadly consistent with the depth of an aseismic zone observed at $>5 \mathrm{~km}$ below the summit, thought to represent the presence of melt (Ratdomopurbo and Poupinet 2000). In addition, an aseismic zone located at $1.5-2.5 \mathrm{~km}$ depth below the summit is interpreted to be a shallow ephemeral storage region, where magma is temporarily stored as it migrates from the deeper reservoir(s) before eruption (Ratdomopurbo and Poupinet 2000). Shallow storage regions have also been proposed based upon Bouguer gravity anomaly data (Saepuloh et al. 2010). The volume of this shallow magma storage region has been estimated at $\sim 1.6-1.7 \times 10^{7} \mathrm{~m}^{3}$ based upon $\left({ }^{210} \mathrm{~Pb}\right)$ in Merapi fumarolic gas and magma residence times as determined from $\left({ }^{210} \mathrm{~Pb} /{ }^{226} \mathrm{Ra}\right)$ disequilibria (Gauthier and Condomines 1999; Le Cloarec and Gauthier 2003). Gas emissions at 
Merapi are $\mathrm{H}_{2} \mathrm{O}$-rich ( 84-95 mol\%), with lesser amounts of $\mathrm{CO}_{2}(<10 \mathrm{~mol} \%)$ and minor amounts of $\mathrm{SO}_{2}$ and $\mathrm{H}_{2} \mathrm{~S}$ (Le Guern et al. 1982; Zimmer and Erzinger 2003). Previous work has concluded that effusive volcanism at Merapi is accompanied by open-system degassing, with most of the degassing occurring within the conduit during ascent or during magma residence in a shallow magma chamber below the summit (Le Pennec et al. 2001; Le Cloarec and Gauthier 2003). Evidence of a deeper gas and magma supply to this shallower system has been reported, with inputs of deep, undegassed magma into the shallower, degassing reservoir (Gauthier and Condomines 1999; Le Cloarec and Gauthier 2003; Costa et al. 2013). For example, volcanic gases are enriched in S compared to modelled volatile phases, attributed to a deeper, reduced, mafic magma supplying $\mathrm{S}$ to the shallow magmatic system (Nadeau et al. 2010, 2013). It is estimated that the magma degassing rate is 40 times greater than the lava extrusion rate of the past 100 years would suggest (Allard et al. 2011). This suggests that the magma storage region is large enough to accommodate substantial amounts of unerupted, degassing magma, with continuous gas percolation through the magma system (Allard et al. 2011). At Merapi, $\mathrm{CO}_{2}$ is thought to originate both from a mantle source and from crustal carbonate assimilation. Isotopic data indicate a mantle-derived origin for most volatiles at Merapi, with additional $\mathrm{CO}_{2}$ derived from crustal contamination (Allard et al. 2011). The upper crustal rocks around Merapi are comprised of a $\sim 10-\mathrm{km}-$ thick sequence of Cretaceous to Tertiary limestones, marls and volcaniclastic rocks (van Bemmelen 1949; Hamilton 1979; Smyth et al. 2005). Calc-silicate xenoliths are commonly found within Merapi lavas, providing evidence for the interaction of magma with crustal carbonate material (e.g. Clocchiatti et al. 1982; Camus et al. 2000; Gertisser and Keller 2003; Chadwick et al. 2007; Deegan et al. 2010; Troll et al. 2012, 2013). Magma-carbonate interaction liberates $\mathrm{CO}_{2}$ through decarbonation reactions of crustal carbonates to the diopside and wollastonite assemblages observed in the xenoliths, adding to the magmatic volatile budget with the potential to sustain and intensify eruptions at Merapi (Deegan et al. 2010; Troll et al. 2012, 2013).

\section{The 2010 and 2006 eruptions of Merapi}

In 2010, Merapi volcano had its largest eruption (VEI 4) since 1872 (e.g. Surono et al. 2012). In contrast to recent prolonged and effusive dome-forming eruptions at Merapi, such as the previous eruption in 2006 (Charbonnier and Gertisser 2008; Preece et al. 2013; Ratdomopurbo et al. 2013), the 2010 eruption began explosively and a new lava dome grew in the newly formed crater prior to explosive destruction of this dome during the peak of the eruption on 5 November 2010, followed by further explosive activity and extrusion of a new dome after 5 November (Surono et al. 2012; Komorowski et al. 2013; Pallister et al. 2013) (Fig. 1). The 2010 eruption chronology and deposits have previously been documented in detail (e.g. Surono et al. 2012; Pallister et al. 2013; Charbonnier et al. 2013; Komorowski et al. 2013). Komorowski et al. (2013) recognised eight stages of the 2010 eruption, which will be referred to throughout this paper (Fig. 1): Stage 1: unrest and magmatic intrusion (31 October 2009-26 October 2010); Stage 2: initial explosions (26 October 2010); Stage 3: recurrent rapid dome growth and destruction (29 October-4 November 2010); Stage 4: paroxysmal dome explosions and collapse (5 November 2010); Stage 5: retrogressive summit collapse (5 November); Stage 6: sub-plinian fountain collapse (5 November 2010); Stage 7: rapid dome growth with alternating effusive and explosive activity (5-8 November 2010); Stage 8: declining ash venting and degassing (8-23 November 2010).

In contrast to 2010, previous episodes of volcanic activity at Merapi over the last century were frequently characterised by prolonged dome extrusion and subsequent gravitational collapse to produce block-and-ash flows (BAFs) or "Merapi-type nuées ardentes" (e.g. Andreastuti et al. 2000; Newhall et al. 2000; Voight et al. 2000; Gertisser et al. 2012a; Surono et al. 2012). The previous eruption in 2006 is a well-characterised extrusive, dome-forming eruption at Merapi (Charbonnier and Gertisser 2008; Gertisser et al. 2012b; Preece et al. 2013; Ratdomopurbo et al. 2013). Although the 2006 eruption displayed typical Merapi dome-forming activity, peak dome extrusion rates reached $3.3 \mathrm{~m}^{3} \mathrm{~s}^{-1}$ (Ratdomopurbo et al. 2013), which is high compared to other recent Merapi eruptions. For example, it is an order of magnitude higher than peak dome extrusion rates in $1994\left(0.32 \mathrm{~m}^{3} \mathrm{~s}^{-1}\right)$ (Ratdomopurbo 1995; Hammer et al. 2000). Throughout the $>3$ month long eruption, BAFs were generated by almost daily gravitational dome collapse. The peak of activity on 14 June 2006 consisted of multiple phases of dome collapse (Charbonnier and Gertisser 2008; Lube et al. 2011; Gertisser et al. 2012b) producing BAFs that travelled up to $7 \mathrm{~km}$ from the summit (Charbonnier and Gertisser 2008).

\section{Methodology}

Samples and sample preparation

Various samples from the different stages of the 2010 eruption were analysed, in particular, samples of dense dome material emplaced on 5 November (Stage 4 of Komorowski et al. 2013), as well as grey scoria and white pumice clasts from PDC deposits emplaced by subsequent convective fountain collapse (Stage 6 of Komorowski et al. 2013). 
Clinopyroxene-hosted silicate melt inclusions were analysed in all samples, and groundmass glass was analysed in all but the dense dome samples, as the groundmass was too crystalline to allow for accurate glass analysis. For comparison, clinopyroxene-hosted melt inclusions and groundmass glass were also analysed from scoriaceous dome fragments from the block-and-ash flows emplaced at the peak of the 2006 eruption on 14 June 2006 (Lobe 1 of Charbonnier and Gertisser 2008; Preece et al. 2013).

Grain mounts were prepared by crushing rock samples for a few seconds in an agate mill, before sieving to different size fractions to separate larger pyroxene phenocrysts. Several hundred clinopyroxene crystals were picked by hand under a binocular microscope from $>1-\mathrm{mm}$ and $>500-\mu \mathrm{m}$-sieve fractions and mounted into low-volatility Struers EpoFix epoxy resin. Each grain mount was polished by hand with aluminium polishing solution down to $0.3 \mu \mathrm{m}$, until melt inclusions were exposed. Aluminium solution was used for polishing in order to avoid carbon and boron contamination, which may occur with diamond solutions. Inclusions were only studied after polishing, with the proviso that some petrographic information may have been lost during polishing. However, this method has the advantage that many melt inclusions can be analysed quickly, giving an extensive overview of the melt inclusion population (cf. Humphreys et al. 2008).

\section{Analytical methods}

Melt inclusions in gold-coated samples were analysed by secondary ion mass spectrometry (SIMS) for isotopes of volatiles $\left({ }^{1} \mathrm{H}^{+}\right.$and $\left.{ }^{12} \mathrm{C}^{+}\right)$and of light lithophile elements $\left({ }^{7} \mathrm{Li}^{+},{ }^{9} \mathrm{Be}^{+},{ }^{11} \mathrm{~B}^{+}\right)$using the Cameca ims-4f ion microprobe at the NERC Ion Microprobe Facility at the University of Edinburgh (UK). A subset of these inclusions were subsequently analysed for ${ }^{12} \mathrm{C}^{+}$at high resolution in order to minimise the interference of ${ }^{24} \mathrm{Mg}^{2+}$ on ${ }^{12} \mathrm{C}^{+}$. All 2010 and $2006 \mathrm{CO}_{2}$ data in this paper are based on the high-resolution ${ }^{12} \mathrm{C}^{+}$results. Analyses were performed using a primary ${ }^{16} \mathrm{O}^{-}$beam and positive secondary ion beam with an accelerating voltage of $4.5 \mathrm{kV}$. Energy filtering with a $75 \pm 20 \mathrm{~V}$ offset, or a $50 \mathrm{~V}$ offset for high-resolution ${ }^{12} \mathrm{C}^{+}$measurements, was used with the purpose of minimising the transmission of unwanted molecular species. Surface contamination was eliminated by performing a $50-\mu \mathrm{m}$-diameter, 10 $\mathrm{nA}$ raster of the sample surface for $3 \mathrm{~min}$ prior to analysis. Results are based on the last 10 cycles, with the first 5 disregarded, or, for high-resolution ${ }^{12} \mathrm{C}^{+}$measurements, based on the last 8 with the first 4 disregarded, in order to abate effects of potential surface contamination and allow time for beam stabilisation. For all analyses, ${ }^{30} \mathrm{Si}^{+}$was used as an internal standard and corrected with $\mathrm{SiO}_{2}$ contents as measured by electron microprobe analysis. $\mathrm{H}_{2} \mathrm{O}$ and $\mathrm{CO}_{2}$ were measured using ${ }^{1} \mathrm{H}^{+}$and ${ }^{12} \mathrm{C}^{+}$, respectively, calibrated using dacitic to rhyolitic glass standards with known $\mathrm{H}_{2} \mathrm{O}$ (up to $4.32 \mathrm{wt} \%$ ) and $\mathrm{CO}_{2}$ (up to $10,380 \mathrm{ppm}$ ) concentrations and using working curves as described in Blundy and Cashman (2008). Standards that were used include the following experimental glasses: Sisson 51, Sisson 56, Sisson 59, RB480, Lipari, STHS, BF147 and MC84r. $\mathrm{CO}_{2}$ backgrounds were measured to be $<5 \mathrm{ppm}$ using $\mathrm{CO}_{2}$-free standards. Detection limits were typically $\sim 10 \mathrm{ppm}$ for $\mathrm{CO}_{2}$ and $\sim 100 \mathrm{ppm}$ for $\mathrm{H}_{2} \mathrm{O}$. Analytical uncertainties based on measurements of the glass standards are $<10 \%$ (relative) for $\mathrm{H}_{2} \mathrm{O}$ and $\sim 10-15 \%$ (relative) for $\mathrm{CO}_{2}$.

Selected melt inclusions in the same polished epoxy grain mounts were also analysed for $\mathrm{H}_{2} \mathrm{O}$ and $\mathrm{CO}_{2}$ using attenuated total reflectance micro-Fourier transform infrared spectroscopy (ATR micro-FTIR) at the USGS, Menlo Park, California. A Ge accessory crystal was used to measure evanescent wave absorption at $3,450 \mathrm{~cm}^{-1}$ (representing total $\mathrm{H}_{2} \mathrm{O}$ ), at $2,350 \mathrm{~cm}^{-1}$ (representing molecular $\mathrm{CO}_{2}$ ) and at $1,400-1,500 \mathrm{~cm}^{-1}$ (representing carbonate) using the methods of Lowenstern and Pitcher (2013).

Each studied melt inclusion and host crystal was viewed with the SEM and analysed by electron probe only after the SIMS analysis in order to avoid possible contamination of $\mathrm{C}$ with the carbon coating. Major elements as well as $\mathrm{Cl}, \mathrm{F}$ and $\mathrm{S}$ in the melt inclusions and groundmass glass were measured using Cameca SX100 electron microprobes at The Open University and the University of Cambridge. Glass was analysed using a defocussed beam diameter of 5-10 $\mu \mathrm{m}$, an accelerating voltage of $15-20 \mathrm{kV}$ and a 4-20 nA beam current for major elements and a 10-20 nA beam current for volatiles. Volatiles were analysed with extended peak counting times. $\mathrm{Na}$ was always measured first to minimise migration effects, and in-house natural mineral standards were used for calibration. Major elements were measured in the clinopyroxene host crystals, near to the site of each melt inclusion, as well as in other clinopyroxene phenocrysts in 2010 and 2006 samples. Although there is little zonation in the analysed clinopyroxene phenocrysts, if zoning was present then pyroxene analyses were made in the same zones in which melt inclusions were situated. Pyroxenes were analysed using a 1-5 $\mu \mathrm{m}$ beam diameter, a $15-20 \mathrm{kV}$ accelerating voltage and a 15 $20 \mathrm{nA}$ beam current. Detection limits were $\sim 100-250 \mathrm{ppm}$ for major elements, $\sim 100 \mathrm{ppm}$ for $\mathrm{S}$ and $\mathrm{Cl}$, and $\sim 200 \mathrm{ppm}$ for F. Analytical uncertainties for major elements, based on repeat analyses of natural mineral and rhyolitic glass standards, were in the order of $1-3 \%$ (relative). Uncertainties of volatile element determinations are estimated at $<5 \%$ (relative) for $\mathrm{S}$ and $\mathrm{Cl}$, and $<15 \%$ (relative) for $\mathrm{F}$.

Back-scattered electron (BSE) images of all melt inclusions were acquired with a JEOL JSM 5900 LV SEM at the University of East Anglia, using an accelerating voltage of 
Fig. 2 Major element variation diagrams showing the composition of melt inclusions from 2010 dense dome material, white pumice and grey scoria, and 2006 scoriaceous dome clasts, as well as groundmass glass and whole-rock compositions from 2006 and 2010 samples. All melt inclusion compositions are corrected for PEC. All melt inclusion, groundmass glass and whole-rock measurements are normalised to $100 \mathrm{wt} \%$ on a volatile-free basis. $\mathrm{FeO}^{*}=$ all iron reported as $\mathrm{FeO}$
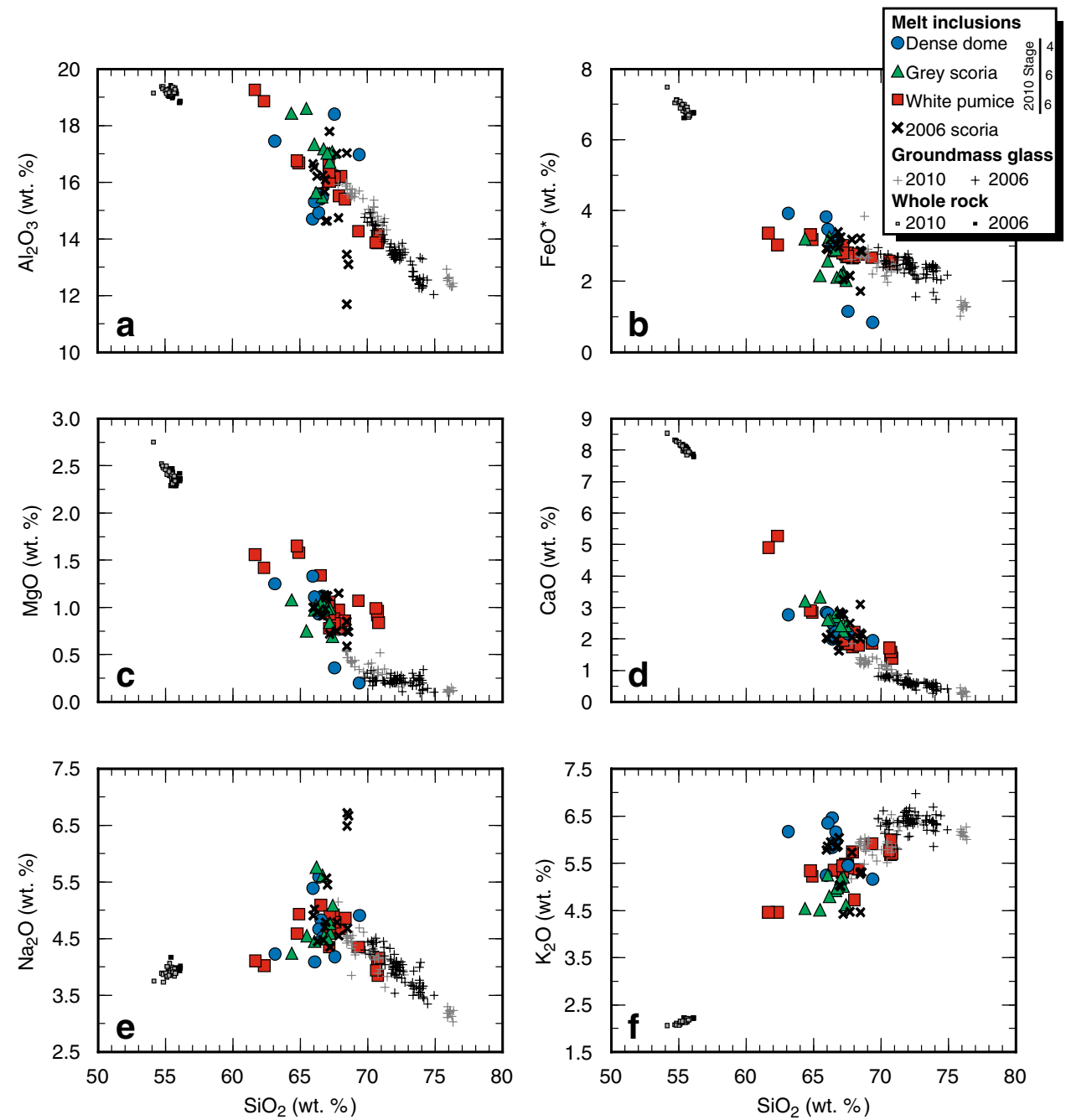

$20 \mathrm{kV}$ and a working distance of $9 \mathrm{~mm}$. All host crystals were imaged using an accelerating voltage of $20 \mathrm{kV}$ and a working distance of 31-37 mm. Back-scattered electron images were then analysed in order to disregard analyses that were on cracks or occasional inclusions which contained any daughter crystals.

Whole-rock compositions were obtained from interior portions of fresh samples, which were washed in Milli$\mathrm{Q}$ in a sonic bath for $15 \mathrm{~min}$, dried overnight at $>100{ }^{\circ} \mathrm{C}$ and powdered in a tungsten carbide mill. Major elements were analysed by X-ray fluorescence (XRF) using a Bruker AXS S4 Pioneer at the University of East Anglia. Loss on ignition (LOI) was carried out by heating in a furnace at $1,050{ }^{\circ} \mathrm{C}$ for $4 \mathrm{~h}$.

All melt inclusion major element data were corrected for the compositional effects of post-entrapment crystallisation (PEC) of clinopyroxene at the melt inclusion-host interface. The corrections were performed by first calculating the composition of the host clinopyroxene that should be in equilibrium with the melt inclusion using an appropriate clinopyroxene-melt equilibrium model (Nielsen and Drake 1979). The equilibrium clinopyroxene was then added in $0.1 \mathrm{wt} \%$ increments to the measured melt inclusion composition until the equilibrium clinopyroxene composition becomes identical to that of the host, using the reverse fractional crystallisation modelling function of the Petrolog3 software (Danyushevsky and Plechov 2011). The calculated degree of PEC is $<10 \%$ but typically $<5 \%$.

\section{Results}

Major element geochemistry

Major element compositional variations in whole rocks, melt inclusions and groundmass glass from 2010 and 2006 samples are shown in Fig. 2. Whole-rock compositions of both the 2010 and 2006 eruptive products are high-K basaltic andesite and show a similar compositional range (Preece et al. 2013; Preece 2014). $\mathrm{SiO}_{2}$ concentrations are between 
54.1 and $55.7 \mathrm{wt} \%$ for 2010 juvenile samples and between 55.2 and $56.1 \mathrm{wt} \%$ for the 2006 products. A comparison of different 2010 lithologies reveals that the compositional range of the dense dome material erupted on 5 November extends to slightly less evolved compositions (54.1$55.6 \mathrm{wt} \% \mathrm{SiO}_{2}$ ) than the white pumice (55.5-55.7 wt $\%$ $\mathrm{SiO}_{2}$ ) and the grey scoria $\left(55.1-55.7 \mathrm{wt} \% \mathrm{SiO}_{2}\right)$, although the differences are marginal. There is a compositional gap of $>5 \mathrm{wt} \% \mathrm{SiO}_{2}$ between the most evolved whole-rock sample and the least evolved melt inclusion (Fig. 2). The melt inclusions are mainly dacitic to rhyolitic in composition, with 63.1-72.4 wt $\% \mathrm{SiO}_{2}$, with only two classed as andesitic (61.7 and $62.3 \mathrm{wt} \% \mathrm{SiO}_{2}$ ) when corrected for PEC and normalised to $100 \%$ on a volatile-free basis (Table 1 and Electronic Supplementary Data). Both 2010 and 2006 melt inclusions cover a similar compositional range. Melt inclusions from each 2010 lithology generally span the entire observed compositional range, although the most evolved melt inclusions $\left(>70 \mathrm{wt} \% \quad \mathrm{SiO}_{2}\right.$ ) come exclusively from white pumice and grey scoria in the 2010 deposits. In comparison, 2006 clinopyroxene-hosted melt inclusions presented in Nadeau et al. (2013) have a more restricted compositional range between 64.2 and $69.8 \mathrm{wt} \%$ $\mathrm{SiO}_{2}$, and in addition, one amphibole-hosted inclusion is reported, which has $64.1 \mathrm{wt} \% \mathrm{SiO}_{2}$. In 1998 dome samples, Schwarzkopf et al. (2001) reported plagioclase-hosted melt inclusions with 56.4-62.6 wt\% $\mathrm{SiO}_{2}$ and Gertisser (2001) reported average values between 63.2 and $66.1 \mathrm{wt} \% \mathrm{SiO}_{2}$ for melt inclusions in different samples of the Merapi high$\mathrm{K}$ series rocks. Groundmass glass compositions represent the most evolved compositions (66.8-76.4 wt\% $\mathrm{SiO}_{2}$ ). Overall trends of $\mathrm{Al}_{2} \mathrm{O}_{3}, \mathrm{CaO}, \mathrm{FeO}^{*}$ (total iron calculated as $\mathrm{FeO}$ ) and $\mathrm{MgO}$ correlate negatively with $\mathrm{SiO}_{2}$, and $\mathrm{K}_{2} \mathrm{O}$ correlates positively with $\mathrm{SiO}_{2}$ (Fig. 2). Both $\mathrm{TiO}_{2}$ and $\mathrm{Na}_{2} \mathrm{O}$ trends are inflexed, with $\mathrm{TiO}_{2}$ concentrations decreasing until $\sim 67 \mathrm{wt} \% \mathrm{SiO}_{2}$ before groundmass $\mathrm{TiO}_{2}$ concentrations increase with increasing $\mathrm{SiO}_{2}$, and $\mathrm{Na}_{2} \mathrm{O}$ correlating positively until $\sim 67 \mathrm{wt} \% \mathrm{SiO}_{2}$, where $\mathrm{Na}_{2} \mathrm{O}$ concentrations begin to decrease.

Volatile concentrations

\section{$\mathrm{H}_{2} \mathrm{O}$ and $\mathrm{CO}_{2}$}

SIMS analysis shows that the highest $\mathrm{H}_{2} \mathrm{O}$ concentrations occur in melt inclusions from the 2010 grey scoria (up to $3.94 \mathrm{wt} \%$ ) and white pumice (up to $3.91 \mathrm{wt} \%$ ) (Table 1). Melt inclusions from 2010 dense dome clasts are generally more degassed, although the highest measured $\mathrm{H}_{2} \mathrm{O}$ in the dome samples is $3.62 \mathrm{wt} \%$. In comparison, melt inclusions from the scoriaceous 2006 dome fragments contain up to $3.73 \mathrm{wt} \% \mathrm{H}_{2} \mathrm{O}$ (Table 1) [see Electronic Supplementary Data for full data set].
$\mathrm{CO}_{2}$ concentrations in melt inclusions are generally $<200$ ppm; although at high $\mathrm{H}_{2} \mathrm{O}$ concentrations, melt inclusions in the white pumice have increased $\mathrm{CO}_{2}$ concentrations up to $695 \mathrm{ppm}$. Several melt inclusions appear to have elevated $\mathrm{CO}_{2}$ concentrations (up to $\sim 3,000 \mathrm{ppm}$ ) at medium $(\sim 2 \mathrm{wt} \%) \mathrm{H}_{2} \mathrm{O}$ contents, a feature particularly associated with melt inclusions from the white pumice. The maximum $\mathrm{CO}_{2}$ measured in the 2010 grey scoria and dense dome melt inclusions is $146 \mathrm{ppm}$ and $12 \mathrm{ppm}$, respectively, and in melt inclusions from the 2006 dome scoria, the maximum is $158 \mathrm{ppm} \mathrm{CO}_{2}$ (Table 1), although one inclusion is displaced towards higher $\mathrm{CO}_{2}$ concentrations $(\sim 2,400 \mathrm{ppm})$ at $<1 \mathrm{wt} \% \mathrm{H}_{2} \mathrm{O}$.

A selected group of 2010 melt inclusions were also analysed for $\mathrm{H}_{2} \mathrm{O}$ and $\mathrm{CO}_{2}$ using ATR micro-FTIR. These inclusions were primarily targeted for ATR micro-FTIR analysis because results from the preceding SIMS analysis suggested that these inclusions were enriched in $\mathrm{CO}_{2}$ (up to $\sim 3,000 \mathrm{ppm})$ at medium $(\sim 2 \mathrm{wt} \%) \mathrm{H}_{2} \mathrm{O}$ contents, relative to the degassing trend displayed by other analysed inclusions (Fig. 3). ATR micro-FTIR results in this study reveal that although measured $\mathrm{H}_{2} \mathrm{O}$ concentrations are similar to the ones acquired by SIMS, the concentration of $\mathrm{CO}_{2}$ in the inclusions was below the detection limit (200 ppm).

Comparison of the melt inclusions analysed in this study with volatile data published by Nadeau et al. (2013) from melt inclusions in clinopyroxene and amphibole phenocrysts and amphibole megacrysts from unknown Merapi eruptions reveal some similarities. Apparent enrichment to comparable elevated levels of $\mathrm{CO}_{2}$ occurs at a similar $\mathrm{H}_{2} \mathrm{O}$ content. However, the highest $\mathrm{H}_{2} \mathrm{O}$ recorded by Nadeau et al. (2013) is only $\sim 2 \mathrm{wt} \%$, even in amphibole megacrysthosted melt inclusions, which is lower than maximum $\mathrm{H}_{2} \mathrm{O}$ concentrations recorded by this study.

\section{$F, S, C l$}

Samples from 2010 show differences in $\mathrm{F}$ concentration, depending upon lithology (Fig. 4). Groundmass glass in white pumice samples contains 632-2,199 ppm F, with the peak at between 1,000 and 1,250 ppm, whereas the groundmass glass in the grey scoria encompasses a larger range of F (180-2,637 ppm), with a peak at relatively higher concentrations of 2,000-2,500 ppm (Fig. 4). Fluorine concentrations in 2010 melt inclusions also vary with lithology. Those trapped in clinopyroxene phenocrysts from dense dome clasts and those from grey scoria have a similar range of $\mathrm{F}$, containing up to $1,400 \mathrm{ppm}$ and $1,480 \mathrm{ppm}$, respectively. White pumice-derived inclusions contain concentrations of $\mathrm{F}$ up to 2,390 ppm (Fig. 4). Melt inclusions from 2006 contain up to $2,050 \mathrm{ppm} \mathrm{F}$, with the groundmass glass containing up to $2,349 \mathrm{ppm}$. Fluorine concentrations in the 2010 and 2006 melt inclusions and groundmass glass 


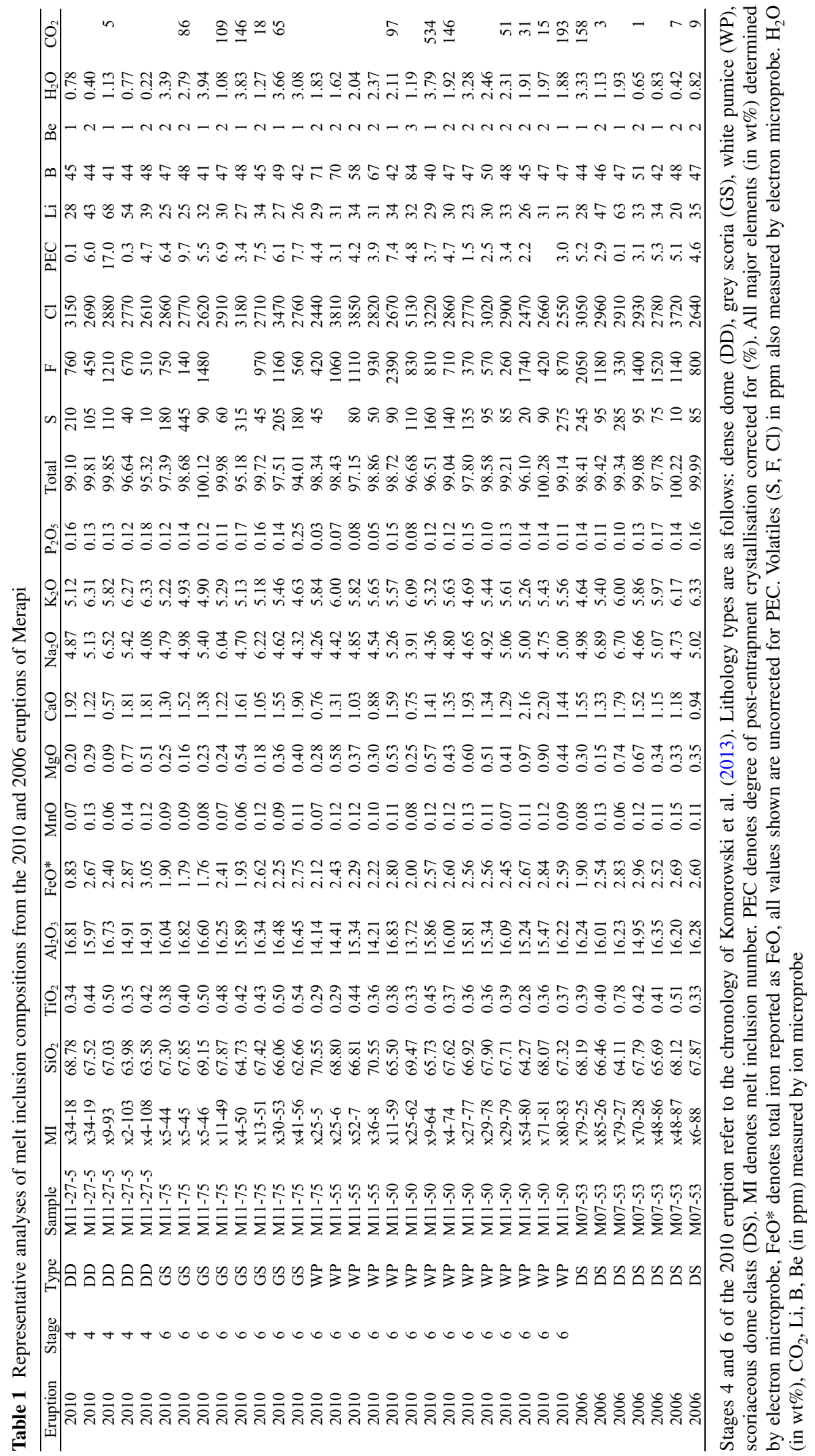



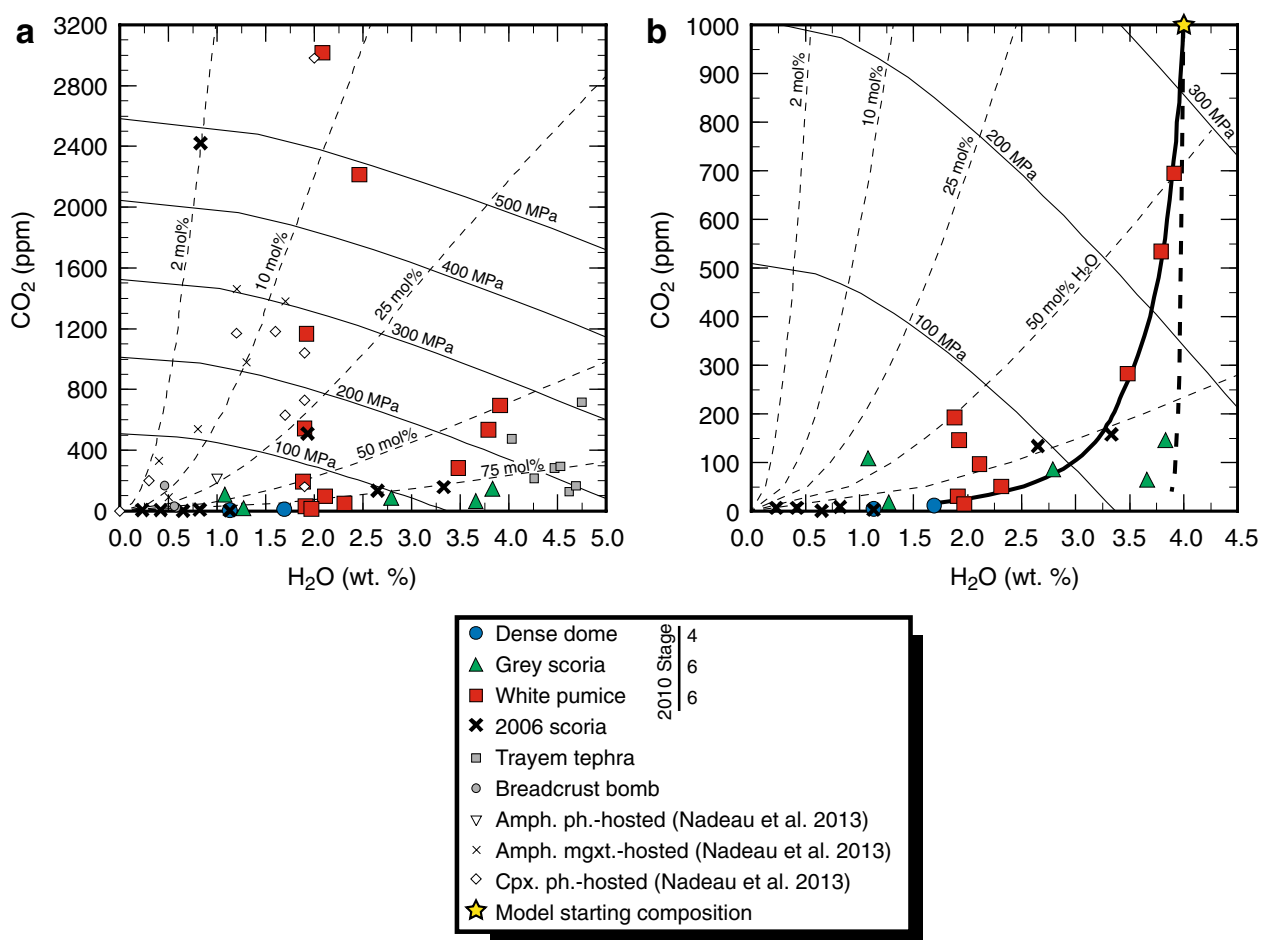

Fig. 3 Melt inclusion $\mathrm{H}_{2} \mathrm{O}$ and $\mathrm{CO}_{2}$ concentrations from SIMS analysis. a $\mathrm{H}_{2} \mathrm{O}$ versus $\mathrm{CO}_{2}$ measured with high-resolution SIMS. All measured melt inclusions including the "high- $\mathrm{CO}_{2}$ " inclusions are shown, some of which were subsequently re-analysed with ATR micro-FTIR. As a comparison to the 2010 and 2006 melt inclusions, clinopyroxene-hosted melt inclusions from two older deposits are also shown, namely a young, widespread basaltic breadcrust bombrich PDC deposit on Merapi's southern flank (Newhall et al. 2000; Gertisser et al. 2012a), tentatively ascribed to the VEI 41872 eruption, the last VEI 4 eruption prior to 2010 (Newhall et al. 2000), and the pumiceous "Trayem tephra" produced during a prehistoric VEI 4 sub-plinian eruption (Gertisser 2001; Gertisser et al. 2012a). Note that the breadcrust bomb and "Trayem tephra" $\mathrm{CO}_{2}$ values were

are similar, although they extend to both higher and lower concentrations compared to the 1994 Merapi dome-forming eruption (Gertisser 2001). In comparison, plagioclasehosted inclusions from the 1998 eruption appear to contain less F, up to 700 ppm (Schwarzkopf et al. 2001), although this may be an artefact of the small sample size reported.

Sulphur is present in low concentrations in all groundmass glass, with $<100$ ppm (detection limit) in 2010 glass and up to $122 \mathrm{ppm}$ in 2006 glass. Melt inclusions are generally more enriched in $\mathrm{S}$ than their respective groundmass, ranging up to $535 \mathrm{ppm} \mathrm{S}$ in 2010 products and up to $345 \mathrm{ppm}$ in inclusions from the 2006 eruption (Fig. 4). Sulphur concentrations of the 2010 and 2006 melt inclusions and groundmass glass are similar to reported concentrations from the 1994 eruption (Gertisser 2001). A similar range of $200-450 \mathrm{ppm} \mathrm{S}$ was also reported for plagioclasehosted melt inclusions from the 1998 eruption (Schwarzkopf et al. 2001). obtained by low-resolution measurements. In addition, previously published data for amphibole phenocryst (Amph. ph.) amphibole megacryst (Amph. mgxt.) and clinopyroxene phenocryst (Cpx. ph.) hosted melt inclusions of unknown origins is also shown (Nadeau et al. 2013). b Enlarged view of measured melt inclusions excluding the "high- $\mathrm{CO}_{2}$ " set. All isobars (fine solid lines) and vapour isopleths (fine dashed lines) calculated with VolatileCalc (Newman and Lowenstern 2002). Closed-system decompression degassing pathway (bold solid line) with $1 \%$ exsolved vapour (bold solid line) starting at $1,000 \mathrm{ppm} \mathrm{CO}_{2}$ and $4.0 \mathrm{wt} \% \mathrm{H}_{2} \mathrm{O}$ at $1,050{ }^{\circ} \mathrm{C}$, and open-system degassing pathway starting at the same conditions (bold dashed line) calculated with VolatileCalc

Chlorine is more enriched in the melt inclusions than in groundmass glass in both 2010 and 2006 samples (Fig. 4). In melt inclusions, the $\mathrm{Cl}$ concentration ranges from 2,060 to $5,130 \mathrm{ppm}$ in 2010 eruptive products, with concentrations most frequently between 2,500 and 3,000 ppm in all sample types. The highest $\mathrm{Cl}$ concentrations are found in melt inclusions hosted in clinopyroxene from white pumice samples. Chlorine concentrations in melt inclusions from the 2006 samples show a comparatively narrow range from 2,330 to 3,720 ppm. The groundmass glass concentrations of $\mathrm{Cl}$ range from $~ 900 \mathrm{ppm}$ up to $3,550 \mathrm{ppm}$ in samples from the 2010 eruption and are between $\sim 1,000$ and $2,920 \mathrm{ppm}$ in those from 2006. The $\mathrm{Cl}$ concentrations in the 2010 and 2006 melt inclusions and groundmass glass are similar to those reported for the 1994 dome-forming eruption (Gertisser 2001), although they extend to both higher and lower values. In comparison, plagioclase-hosted inclusions from recent eruptions contain a similar range of 
Fig. 4 Volatile contents in melt inclusions and groundmass glass plotted against differentiation indicator $\mathrm{K}_{2} \mathrm{O}$ wt $\%$. a F versus $\mathrm{K}_{2} \mathrm{O}$, b S versus $\mathrm{K}_{2} \mathrm{O}$, c $\mathrm{Cl}$ versus $\mathrm{K}_{2} \mathrm{O}$. Detection limits are displayed as dashed lines
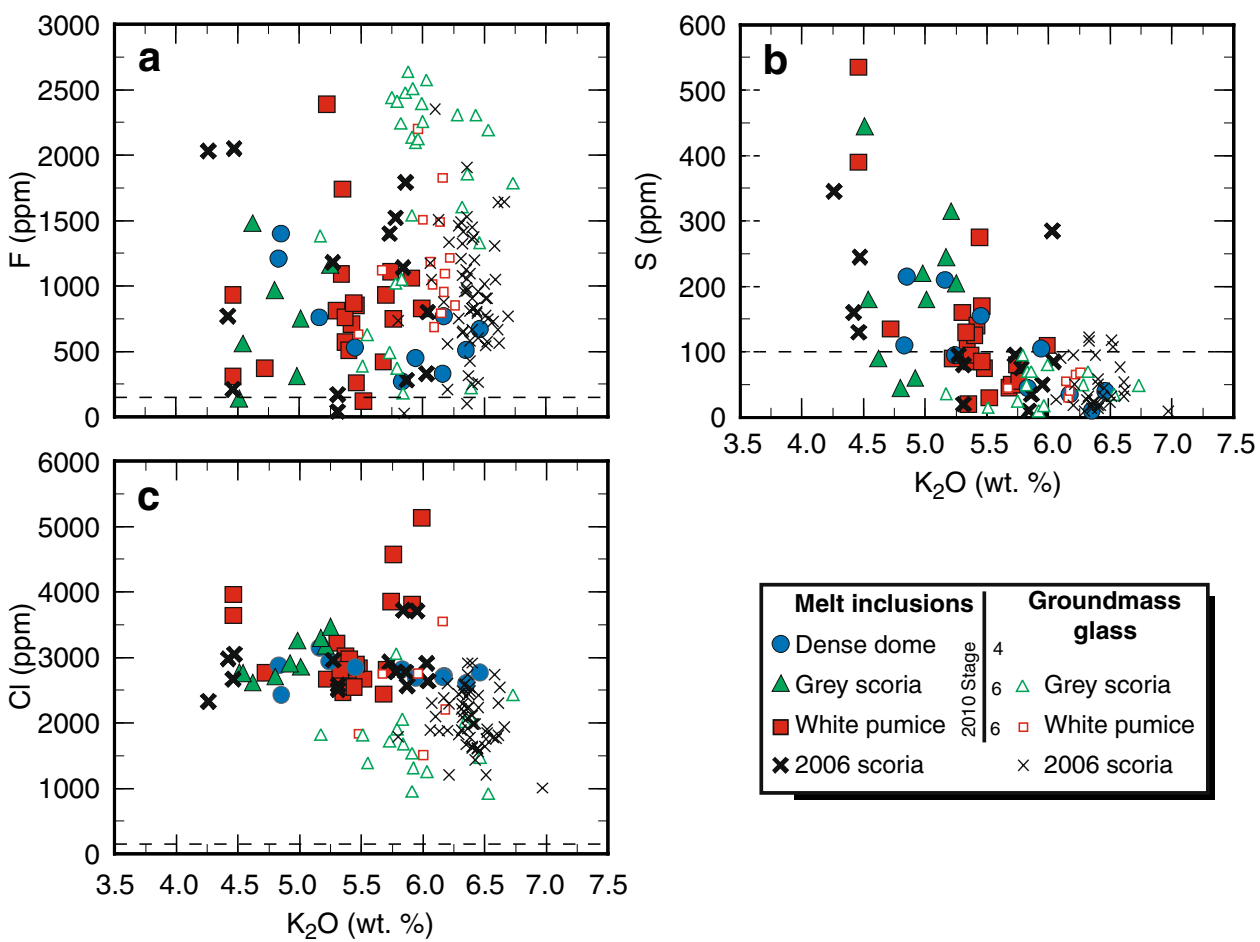

between 3,010 and 3,320 pm Cl (Gertisser 2001), although Schwarzkopf et al. (2001) report high concentrations of up to $7,000 \mathrm{pm} \mathrm{Cl}$ in plagioclase-hosted inclusions from the 1998 eruption.

\section{Light lithophile elements (B, Be and Li)}

Concentrations of light lithophile elements, especially those of $\mathrm{B}$ and $\mathrm{Li}$, indicate differences within the melt inclusion population. Beryllium concentrations are uniform, with all measured melt inclusions containing 1-2 ppm, while Li concentrations vary from $20-68 \mathrm{ppm}$. When plotted against $\mathrm{H}_{2} \mathrm{O}$ and $\mathrm{Cl}$ (Fig. 5), divergent L-shaped trends show enrichment of $\mathrm{Li}(>\sim 35 \mathrm{ppm})$ in melt inclusions from the 2010 dense dome material and the 2006 scoria, which also show low $\mathrm{H}_{2} \mathrm{O}$ concentrations and $\sim 2,700 \mathrm{ppm}$ $\mathrm{Cl}$. There is no obvious correlation between $\mathrm{Li}$ and $\mathrm{SiO}_{2}$ or $\mathrm{K}_{2} \mathrm{O}$ (Fig. 5). The overall range in $\mathrm{B}$ concentration is $35-$ $109 \mathrm{ppm}$, with enrichment (> 55 ppm) in melt inclusions from white pumice that contain intermediate $\mathrm{H}_{2} \mathrm{O}$ concentrations ( 1-2.5 wt\%) and $\mathrm{Cl}$ up to $\sim 5,000$ ppm (Fig. 5). Boron-enriched inclusions show a positive correlation with $\mathrm{SiO}_{2}$ and $\mathrm{K}_{2} \mathrm{O}$, but when plotted against $\mathrm{Li}$, the data show a divergent L-shaped trend (Fig. 5).

\section{Clinopyroxene compositions}

The major element composition of clinopyroxene host crystals was measured alongside that of other pyroxene phenocrysts within the same eruptive products to establish whether there are systematic compositional variations between different eruptive products and whether host crystals are representative of the clinopyroxene population. Of the 2010 lithologies, clinopyroxene from the dome samples have the widest compositional range $\left(\mathrm{Wo}_{40-50} \mathrm{En}_{33-}\right.$ ${ }_{45} \mathrm{Fs}_{12-24}$ ) with the presence of crystals containing higher proportions of Wo and Fs, and lower En components compared to the grey scoria $\left(\mathrm{Wo}_{42-47} \mathrm{En}_{38-44} \mathrm{Fs}_{12-15}\right)$ and the white pumice $\left(\mathrm{Wo}_{41-48} \mathrm{En}_{36-45} \mathrm{Fs}_{13-16}\right)$ (Fig. 6). Analysed clinopyroxene phenocrysts from the 2006 dome scoria are similar in composition $\left(\mathrm{Wo}_{41-48} \mathrm{En}_{36-45} \mathrm{Fs}_{13-17}\right)$ to those from the 2010 eruption (Table 2). The magnesium number $\left[\mathrm{Mg} \#=100 \times \mathrm{Mg} /\left(\mathrm{Mg}+\mathrm{Fe}^{2+}\right)\right]$ of the 2006 pyroxenes $(\mathrm{Mg} \#=76-83)$ also overlaps with the range of 2010 phenocrysts $(\mathrm{Mg} \#=61-86)$. The 2010 dome samples have the largest range in $\mathrm{Mg \#} \mathrm{(61-86),} \mathrm{although} \mathrm{most} \mathrm{crystals}$ analysed from the dome lie between Mg\# 71-84 (Table 2). In comparison, grey scoria and white pumice samples contain clinopyroxene phenocrysts with $\mathrm{Mg} \#=77-83$ and $\mathrm{Mg} \#=75-84$, respectively. Although the majority of clinopyroxene phenocrysts from the 2010 and 2006 samples contain $\sim 1-3 \mathrm{wt} \% \mathrm{Al}_{2} \mathrm{O}_{3}$, the 2010 dome crystals display the largest variation, with values ranging between 0.4 and $8.9 \mathrm{wt} \%$. Other lithologies from the 2010 eruption also contain relatively high- $\mathrm{Al}_{2} \mathrm{O}_{3}$ clinopyroxene, with phenocrysts from the white pumice containing 1.4-7.0 wt $\% \mathrm{Al}_{2} \mathrm{O}_{3}$ while those from the grey scoria contain 1.4-4.8 $\mathrm{wt} \% \mathrm{Al}_{2} \mathrm{O}_{3}$. These values are similar to previous analyses of 2010 and 
2006 Merapi clinopyroxenes, for which concentrations of 2-8 wt $\%$ and 1.5-6.5 wt $\% \mathrm{Al}_{2} \mathrm{O}_{3}$ are reported (Costa et al. 2013). In comparison, the 2006 clinopyroxene samples analysed here generally encompass a more restricted range, with 1.4-3.8 wt $\% \mathrm{Al}_{2} \mathrm{O}_{3}$, and a single analysis recording an elevated $\mathrm{Al}_{2} \mathrm{O}_{3}$ content of $6.7 \mathrm{wt} \%$ (Fig. 6). The clinopyroxene phenocrysts hosting the melt inclusions that were used for SIMS analysis sample the compositional range found within the entire 2010 and 2006 clinopyroxene populations, although they do not sample the highest $\mathrm{Al}_{2} \mathrm{O}_{3}$ contents, as the analysed host crystals contain a maximum of $5.6 \mathrm{wt} \% \mathrm{Al}_{2} \mathrm{O}_{3}$ only (see Table 2 and Electronic Supplementary Data).

\section{Discussion}

Interpreting SIMS and ATR micro-FTIR $\mathrm{H}_{2} \mathrm{O}$ and $\mathrm{CO}_{2}$ data

The scatter in melt inclusion $\mathrm{H}_{2} \mathrm{O}$ and $\mathrm{CO}_{2}$ concentrations in the SIMS data (Fig. 3a), with elevated $\mathrm{CO}_{2} / \mathrm{H}_{2} \mathrm{O}$ compared to equilibrium degassing trends, has frequently been noted in melt inclusions from subduction systems (Atlas et al. 2006; Johnson et al. 2008; Vigouroux et al. 2008; Blundy et al. 2010; Berlo et al. 2012; Nadeau et al. 2013; Reubi et al. 2013). This feature is commonly interpreted as being the result of magma mixing (e.g. Atlas et al. 2006), complex degassing histories, involving $\mathrm{CO}_{2}$ fluxing (Johnson et al. 2008; Vigouroux et al. 2008; Blundy et al. 2010; Nadeau et al. 2013) or non-equilibrium degassing (Gonnermann and Manga 2005), or alternatively, due to post-entrapment diffusive loss of $\mathrm{H}_{2} \mathrm{O}$ or $\mathrm{H}^{+}$(Berlo et al. 2012; Reubi et al. 2013). At Merapi, elevated $\mathrm{CO}_{2} / \mathrm{H}_{2} \mathrm{O}$ concentrations in amphibole and pyroxene-hosted melt inclusions have previously been observed and interpreted to reflect $\mathrm{CO}_{2}$ fluxing and the liberation of $\mathrm{CO}_{2}$-rich gas via crustal carbonate assimilation (Nadeau et al. 2013). If a significant amount of $\mathrm{CO}_{2}$ invades the system, the increase in partial pressure of $\mathrm{CO}_{2}$ and corresponding decreasing partial pressure of $\mathrm{H}_{2} \mathrm{O}$ results in increasing $\mathrm{CO}_{2} / \mathrm{H}_{2} \mathrm{O}$ in the melt, shifting melt inclusion compositions isobarically towards higher $\mathrm{CO}_{2}$ and lower $\mathrm{H}_{2} \mathrm{O}$ compositions. Crustal assimilation at Merapi has been shown to have played a part in the 2010 and 2006 eruptions of Merapi, evidenced by elevated (compared to mantle values) whole-rock and phenocryst $\delta^{18} \mathrm{O}$ values (Borisova et al. 2013; Troll et al. 2013). However, the question still remains as to whether $\mathrm{CO}_{2}$ liberation from shallow $(<10 \mathrm{~km})$ crustal sediments is likely to be recorded in melt inclusions. At the inferred shallow depth $(<10 \mathrm{~km})$ and associated low pressure of crustal $\mathrm{CO}_{2}$ liberation, it is unlikely that the $\mathrm{CO}_{2}$ is redissolved back into the melt. Instead, $\mathrm{CO}_{2}$ is more likely to be lost through fumarolic activity or diffuse degassing
(Holloway and Blank 1994; Toutain et al. 2009; Troll et al. 2012). Large increases of $\mathrm{CO}_{2} / \mathrm{SO}_{2}, \mathrm{CO}_{2} / \mathrm{HCl}$ and $\mathrm{CO}_{2} / \mathrm{H}_{2} \mathrm{O}$ were detected in fumarolic gases in the months leading up to the 2010 eruption, with a dramatic increase in $\mathrm{CO}_{2}$ abundance from $10 \mathrm{~mol} \%$ in September 2010 up to $35-63 \mathrm{~mol} \%$ on 20 October, interpreted to be due to a progressive shift to degassing of a deeper magmatic source (Surono et al. 2012). $\mathrm{CO}_{2}$ fluxing is a process that likely takes place at Merapi and occurred prior to the 2010 and 2006 eruptions, both from depth and from the crust (Surono et al. 2012; Borisova et al. 2013; Troll et al. 2013). However, isobaric dehydration due to $\mathrm{CO}_{2}$ fluxing should result in melt inclusion compositions positioned along isopleth lines on a $\mathrm{H}_{2} \mathrm{O}-\mathrm{CO}_{2}$ plot and show a relatively continuous range of $\mathrm{H}_{2} \mathrm{O}$ and $\mathrm{CO}_{2}$ contents (Reubi et al. 2013). The Merapi melt inclusion data (Fig. 3) are inconsistent with this expected trend, and so, although $\mathrm{CO}_{2}$ fluxing may be occurring at Merapi, it is not likely that evidence of this process is preserved in the studied set of melt inclusions.

Diffusive loss of $\mathrm{H}^{+}$can displace melt inclusion compositions to high $\mathrm{CO}_{2}$ concentrations compared to degassing trends. This process is often accompanied by $\mathrm{Fe}$ oxidation and magnetite precipitation (Danyushevsky et al. 2002). Magnetite daughter crystals were noted in some Merapi melt inclusions, but none of these inclusions was chosen for analysis. Significant diffusive loss of molecular $\mathrm{H}_{2} \mathrm{O}$ is expected to result in crystallisation of daughter crystals and decrepitation of the melt inclusion (Danyushevsky et al. 2002), and has been shown experimentally to cause the formation of shrinkage bubbles (Severs et al. 2007). No decrepitation was observed and although, as noted above, some Merapi melt inclusions contain small daughter crystals, none of these inclusions was chosen for analysis. There is also no correlation between $\mathrm{H}_{2} \mathrm{O}$ and $\mathrm{CO}_{2}$ content with calculated degree of PEC. Small bubbles were noted occasionally in melt inclusions, indicating that $\mathrm{H}_{2} \mathrm{O}$ loss may have occurred in a small percentage of inclusions. In the presence of shrinkage bubbles, $\mathrm{CO}_{2}$ values in the melt inclusion would represent minimum values, as $\mathrm{CO}_{2}$ preferentially partitions into the bubble, decreasing the concentration of $\mathrm{CO}_{2}$ in the melt with increasing dehydration (e.g. Bucholz et al. 2013). Sub-micron bubbles, which may not be detected during observation of the melt inclusions, could result in high $\mathrm{CO}_{2}$ values, if sputtered during analysis. However, ${ }^{12} \mathrm{C}^{+}$counts were recorded during each cycle of SIMS analysis and counts always remained stable, indicating that $\mathrm{CO}_{2}$ concentrations are homogenous over the spatial extent of each analysis, precluding the possibility that the high $\mathrm{CO}_{2}$ measurements are due to sub-micron bubbles. Diffusive loss of $\mathrm{H}_{2} \mathrm{O}$ has been shown experimentally to occur on timescales of hours to days in olivine (Portnyagin et al. 2008; Chen et al. 2011; Gaetani et al. 2012). No experimental data for $\mathrm{H}_{2} \mathrm{O}$ loss from clinopyroxene-hosted 

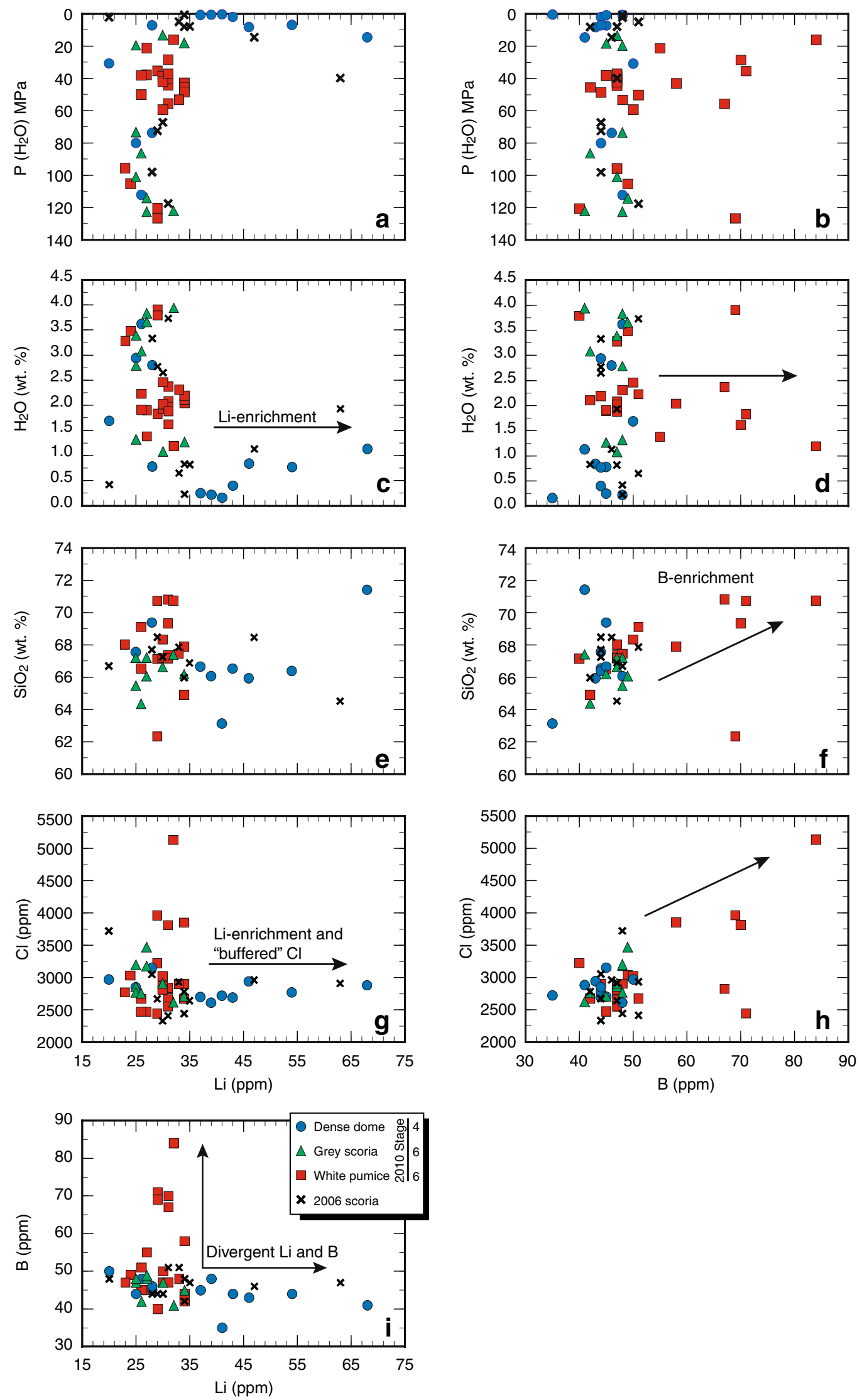
4Fig. 5 Light lithophile element ( $\mathrm{Li}$ and $\mathrm{B}$ ) concentrations in melt inclusions, showing that $\mathrm{Li}$ is enriched in melt inclusions from the 2010 dense dome clasts and the 2006 scoriaceous dome clasts, and $\mathrm{B}$ is enriched in white pumice melt inclusions. $\mathbf{a}, \mathbf{b} \mathrm{Li}$ and $\mathrm{B}$ versus $\mathrm{P}\left(\mathrm{H}_{2} \mathrm{O}\right), \mathbf{c}, \mathbf{d ~ L i}$ and $\mathrm{B}$ versus $\mathrm{H}_{2} \mathrm{O}, \mathbf{e}, \mathbf{f} \mathrm{Li}$ and $\mathrm{B}$ versus $\mathrm{SiO}_{2}, \mathbf{g}, \mathbf{h ~} \mathrm{Li}$ and $\mathrm{B}$ versus $\mathrm{Cl}, \mathbf{i}$ Li versus $\mathrm{B}$

melt inclusions are available. However, Reubi et al. (2013) determined that diffusion coefficients for natural pyroxene-hosted melt inclusions are several orders of magnitude smaller than experimentally determined $\mathrm{H}^{+}$diffusion coefficients (Hercule and Ingrin 1999; Stalder and Skogby 2003), and proved that pyroxene-hosted melt inclusions can preserve $\mathrm{H}_{2} \mathrm{O}$ values close to entrapment values, even in dome samples formed during low effusions rates $\left(\sim 0.6 \mathrm{~m}^{3}\right.$ $\left.\mathrm{s}^{-1}\right)$. In addition, melt inclusions from slowly cooled samples are more prone to diffusive $\mathrm{H}_{2} \mathrm{O}$ loss (Hauri et al. 2002; Portnyagin et al. 2008; Lloyd et al. 2013). Therefore, although a small amount of diffusive $\mathrm{H}_{2} \mathrm{O}$ loss cannot be ruled out, and may possibly account for high $\mathrm{CO}_{2} /$ $\mathrm{H}_{2} \mathrm{O}$ in some melt inclusions from 2006 dome samples, it is unlikely that such a process is the primary cause of the apparently high $\mathrm{CO}_{2}$ values in the white pumice melt inclusions, which are expected to be the fastest erupted and cooled samples in this study.

Comparison of the SIMS data with the ATR microFTIR data collected in this study is essential to shed light on the apparently high $\mathrm{CO}_{2} / \mathrm{H}_{2} \mathrm{O}$ melt inclusions in the white pumice. When a subset of the high $\mathrm{CO}_{2} / \mathrm{H}_{2} \mathrm{O}$ inclusions (as measured by SIMS) was subsequently measured by FTIR, no $\mathrm{CO}_{2}$ was detected (detection limit 200 ppm). A possible explanation for the discrepancy could be due to the fact that SIMS measures ${ }^{12} \mathrm{C}^{+}$and FTIR measures $\mathrm{CO}_{2}$. Any ${ }^{12} \mathrm{C}^{+}$that is present in the melt inclusions as carbonate would not be recorded in the spectrum at $2,350 \mathrm{~cm}^{-1}$, but in the range of $1,400-1,500 \mathrm{~cm}^{-1}$. However, this range was also monitored during FTIR analysis, and no carbonate was detected (detection limit $500 \mathrm{ppm}$ ). The discrepancy between the SIMS and ATR micro-FTIR data sets is potentially caused by heterogeneities in the distribution of $\mathrm{CO}_{2}$ in the melt inclusion. The sampling volume of the two techniques is different, with SIMS sampling a smaller region of the inclusion than FTIR. In this respect, FTIR would not detect any heterogeneity, giving only an average $\mathrm{CO}_{2}$ concentration of the inclusion, whereas SIMS analysis will sample a smaller area within each inclusion,
Fig. 6 Clinopyroxene phenocryst compositions. a $\mathrm{Al}_{2} \mathrm{O}_{3}$ (wt \%) versus Wo (mol\%) (wollastonite end-member) of all measured clinopyroxene phenocrysts in 2010 and 2006 products, including the phenocrysts that host melt inclusions used in this paper (white symbols), as well as other phenocrysts from the same eruptive products (black symbols). b $\mathrm{Al}_{2} \mathrm{O}_{3}$ (wt \%) versus Wo $(\mathrm{mol} \%)$ in the host phenocrysts, divided into eruptive stages. c $\mathrm{Al}_{2} \mathrm{O}_{3}$ (wt \%) versus $\mathrm{Mg \#}$ of all measured clinopyroxene phenocrysts in 2010 and 2006 products, including the host phenocrysts (white symbols) that host melt inclusions used in this paper, as well as other phenocrysts from the same eruptive products (black symbols). d $\mathrm{Al}_{2} \mathrm{O}_{3}$ (wt \%) versus $\mathrm{Mg} \#$ in the host phenocrysts, divided into eruptive stages
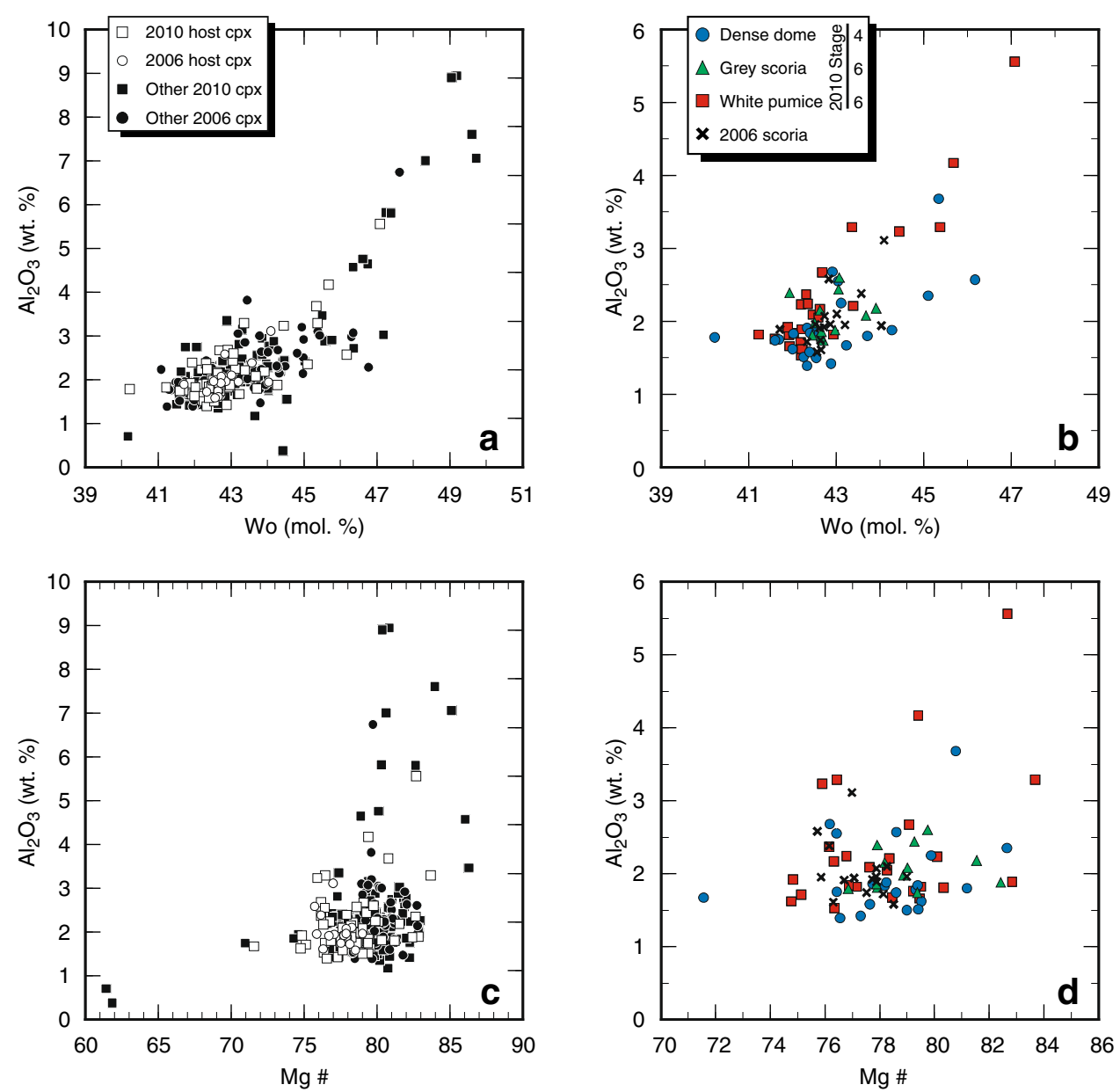


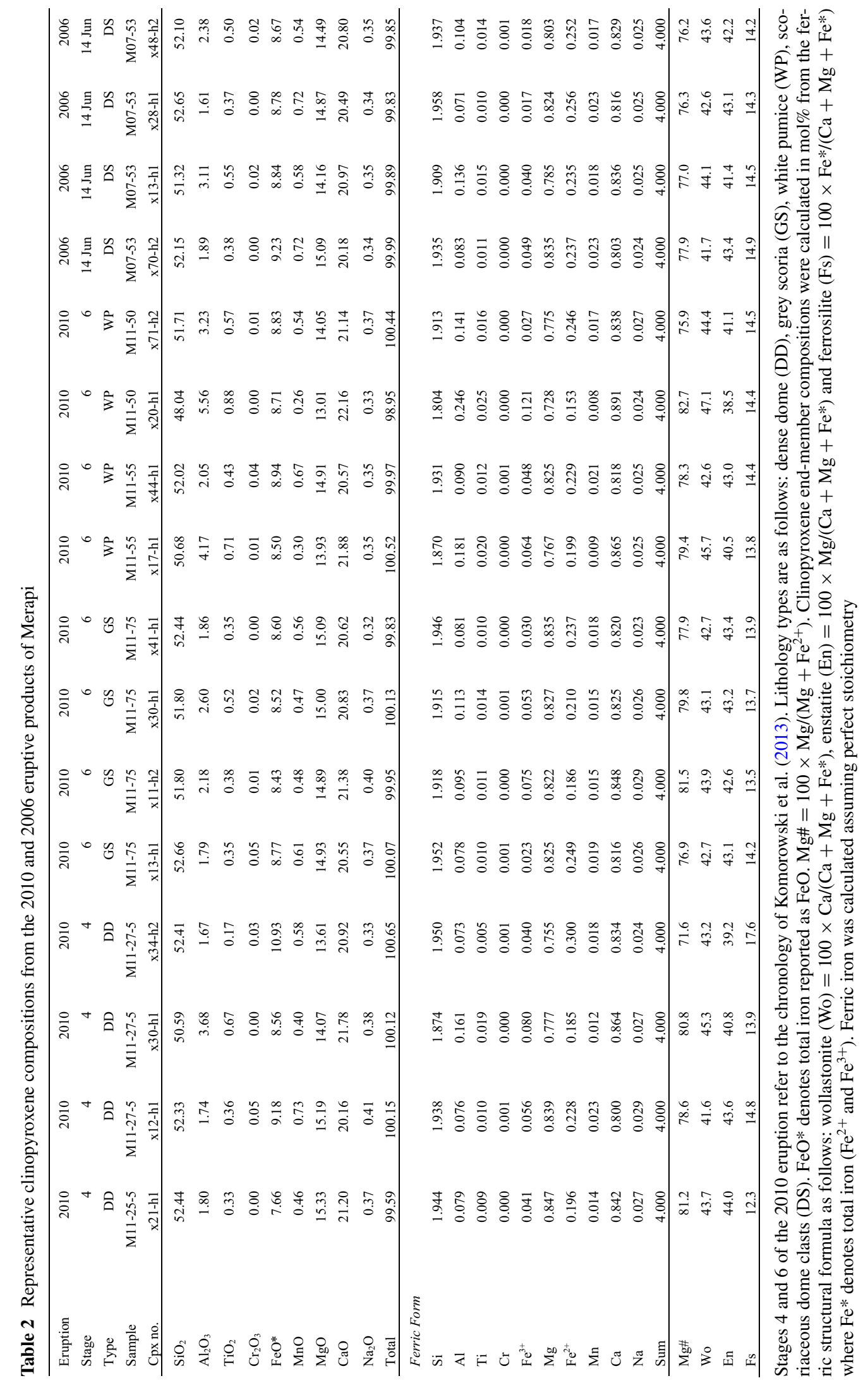


possibly enabling the detection of any heterogeneity. The idea of heterogeneous distribution of $\mathrm{CO}_{2}$ in the melt inclusions is supported by the analysis of one melt inclusion that was large enough to be analysed by SIMS in two separate areas, with one measurement of $1,167 \mathrm{ppm} \mathrm{CO}_{2}$ and one of $146 \mathrm{pm} \mathrm{CO}_{2}$. A low $\mathrm{CO}_{2}$ inclusion from the 2006 dome scoria was large enough to analyse twice and both analyses yielded similar results, although other melt inclusions were too small to obtain multiple analyses. Possible causes for the heterogeneous distribution of $\mathrm{CO}_{2}$ in the white pumice melt inclusions may be linked to a post-entrapment process. For example, potential heterogeneity may be linked to the proximity of the SIMS analysis spot with a bubble not in the plane of view. If $\mathrm{CO}_{2}$ diffuses into the bubble, this may possibly result in heterogeneous distribution of $\mathrm{CO}_{2}$ within the inclusion. Although no bubbles were observed in these inclusions, it is possible that they were not in the plane of view or were removed during the polishing process. Another possibility may be that $\mathrm{CO}_{2}$ diffusion, unlike the relatively fast diffusion of $\mathrm{H}_{2} \mathrm{O}$ (e.g. Zhang et al. 1991), cannot keep up with host crystallisation after entrapment, potentially becoming highly concentrated in some areas and resulting in heterogeneity. This hypothesis may help to explain why apparent $\mathrm{CO}_{2}$ enrichment is only seen in rapidly ejected white pumice samples and not in those from the 2010 dome material, which extruded more slowly, potentially allowing time for re-equilibration of the $\mathrm{CO}_{2}$ in the inclusion. Although beyond the scope of this work, heterogeneous $\mathrm{CO}_{2}$ distribution in natural silicate melt inclusions is an important issue that demands further work to understand fully. If the high $\mathrm{CO}_{2} / \mathrm{H}_{2} \mathrm{O}$ ratios in these inclusions are due to a post-entrapment process, then other melt inclusions showing the same trend need to be interpreted with caution. In the light of this, the apparently elevated $\mathrm{CO}_{2}$ values are reported here but have not been used in the reconstruction of magmatic degassing pathways and equilibration pressures. The remaining $\mathrm{CO}_{2}$ measurements are retained as they reproduce modelled trends for equilibrium degassing, thereby giving additional confidence in results.

\section{Clinopyroxene crystallisation and melt inclusion entrapment}

The crystallisation pressures of melt inclusion-hosting clinopyroxene phenocrysts were calculated using three different barometers (Fig. 7). The first is a clinopyroxenemelt model, which is based on the $\mathrm{Al}$ partitioning between clinopyroxene and liquid, calibrated for hydrous systems by Putirka (2008, Eq. 32c). The model requires an input of $\mathrm{H}_{2} \mathrm{O}$ concentration ( $4 \mathrm{wt} \%$ used, as determined by the maximum measured $\mathrm{H}_{2} \mathrm{O}$ concentration in melt inclusions) and an estimated temperature, calculated using the Putirka et al. (2003) thermometer (range between 1,025 and $\left.1,058{ }^{\circ} \mathrm{C}\right)$. The andesitic to rhyolitic compositions of the melt inclusions and groundmass glass are not in equilibrium with the clinopyroxene host (e.g. the $\mathrm{Mg} / \mathrm{Fe}$ equilibrium criterion of Putirka (2008) is not met). Therefore, a basaltic andesite bulk rock composition with $~ 55.5 \mathrm{wt} \%$ $\mathrm{SiO}_{2}$ was used, which is representative of the composition of the 2010 and 2006 products and satisfies the equilibrium criteria. The model has a standard error of estimate (SEE) of $\pm 150 \mathrm{MPa}$ and has recently yielded satisfactory results for similar Indonesian volcanic systems (Dahren et al. 2012; Jeffery et al. 2013). The second barometer is that of Putirka (2008), which is a recalibrated version of Nimis (1995) suitable for hydrous systems and based only upon the clinopyroxene composition. The recalibration aims to remove the systematic error associated with the Nimis (1995) barometer, which can yield low pressure estimates, at the cost of requiring an $\mathrm{H}_{2} \mathrm{O}$ estimate in addition to the temperature input already needed. The SEE is $\pm 260 \mathrm{MPa}$ (Putirka 2008). As an additional test, a second clinopyroxene barometer was employed using $C p x B a r$ (Nimis 1999), an Excel spreadsheet based upon the pressure-dependent clinopyroxene unit cell arrangement. Calculations for the Merapi clinopyroxenes utilised the mildly alkaline series calibration (standard error: $200 \mathrm{MPa}$ ), with a temperature input of $1,050{ }^{\circ} \mathrm{C}$. The range of 2010 clinopyroxene $(n=57)$ crystallisation pressures obtained by all three models is within error of each other: 80-510 $( \pm 150)$ MPa (Putirka 2008, Eq. 32c), -60 to $430( \pm 260) \mathrm{MPa}$ (Putirka 2008, Eq. 32b) and 20-540 ( \pm 200$) \mathrm{MPa}$ (Nimis 1999), equivalent to depths of 2.9-18.6 ( \pm 5.5$) \mathrm{km}, 0-15.7$ $( \pm 9.5) \mathrm{km}$ and 0.7-19.7 $( \pm 7.3) \mathrm{km}$, respectively (Fig. 7), assuming an average crustal density of $2,800 \mathrm{~kg} / \mathrm{m}^{3}$, as also used in depth calculations at Merapi by Costa et al. (2013). Taking into account the pressure range obtained by all three models, crystallisation pressures of the 2006 clinopyroxenes $(n=15)$ lie within a similar, albeit more restricted range of 120-420 MPa, equivalent to depths of 4.4-15.3 km. One striking feature of the data is that the "deepest" crystals are from the white pumice samples, with $80 \%$ of those crystallised at $P>300 \mathrm{MPa}$ using the Putirka (2008) models (Eq. 32b and 32c), and nearly $80 \%$ of the those crystallised at $P>400 \mathrm{MPa}$ using the Nimis (1999) model, originating from the white pumice (Fig. 7). This is consistent with results from amphibole barometry (Preece 2014), which also suggest that the "deepest" amphibole crystals are from white pumice samples. In comparison, Costa et al. (2013) proposed that the 2010 magma was stored within a multi-depth plumbing system comprising: (1) a deep reservoir at $30( \pm 3) \mathrm{km}$ or $\sim 800 \mathrm{MPa}$, as evidenced by some amphiboles and high-Al clinopyroxene, (2) a reservoir at intermediate depths of 13 $( \pm 2) \mathrm{km}$ or 300-450 MPa, where other amphiboles, high$\mathrm{Al}$ cpx and high-An plagioclase grew and (3) a shallow 

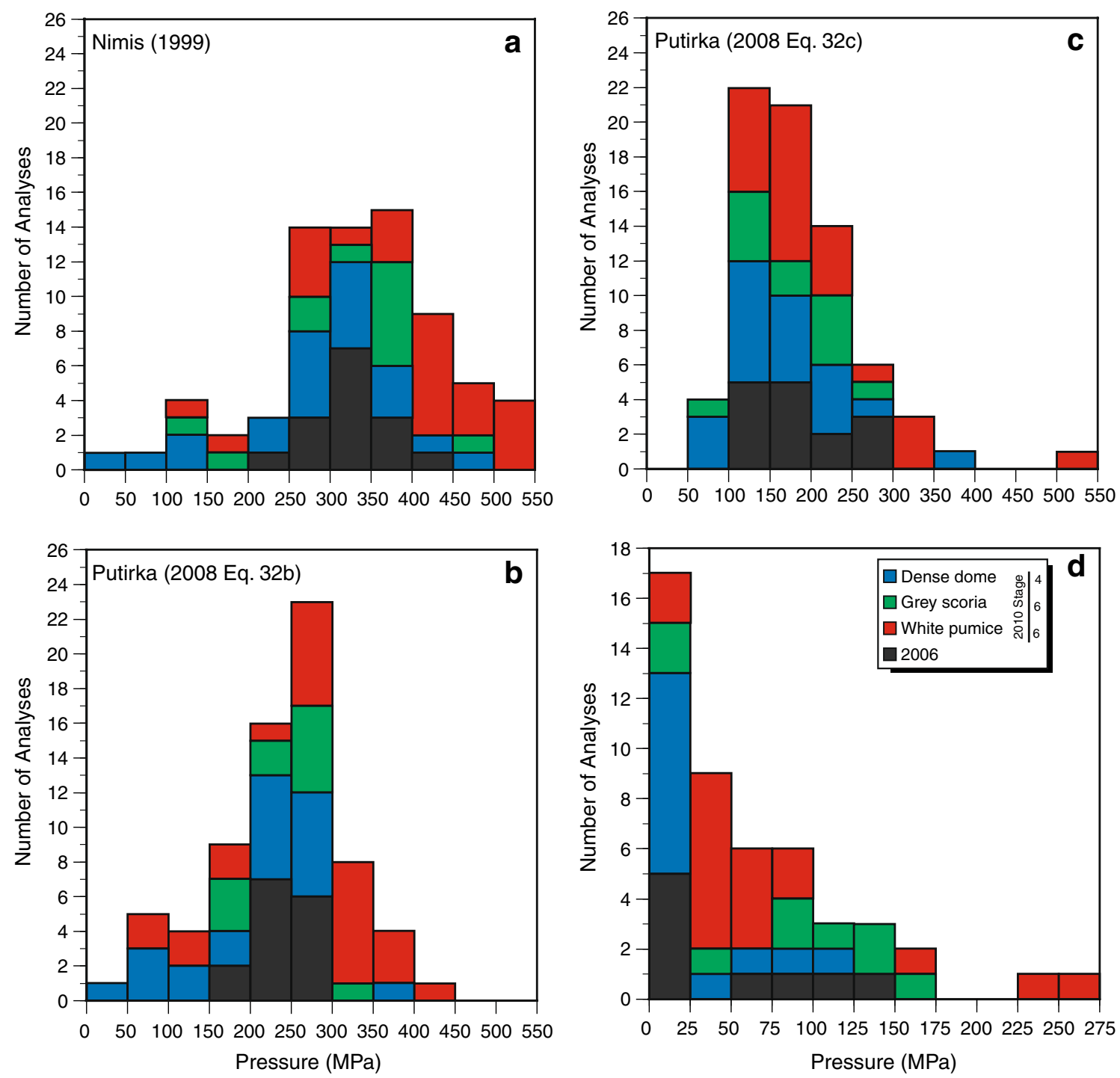

Fig. 7 Histograms to show pressure (MPa) of clinopyroxene host crystallisation. a Calculated with CpxBar (Nimis 1999) using the MA (mildly alkaline) calibration at $1,050{ }^{\circ} \mathrm{C}$. b calculated using Equation 32b of Putirka (2008), one value of minus pressure not plotted. c Calculated using Equation 32c of Putirka (2008). d Histogram of

last re-equilibration pressures (MPa) of melt inclusions from different 2010 stages and from 2006, calculated using VolatileCalc (Newman and Lowenstern 2002) at $1,050{ }^{\circ} \mathrm{C}$, based on melt inclusion $\mathrm{H}_{2} \mathrm{O}$ and $\mathrm{CO}_{2}$ concentrations

reservoir at $<10 \mathrm{~km}(\sim 100 \mathrm{MPa})$ where extensive crystallisation produced low-Al cpx, orthopyroxene and plagioclase. The clinopyroxenes analysed in this study therefore appear to have crystallised in a depth range consistent with the intermediate and shallow magma storage zones proposed by Costa et al. (2013).

The wide variation of $\mathrm{H}_{2} \mathrm{O}$ concentrations in melt inclusions suggests that some inclusions have ruptured on timescales that were long enough to allow the escape of $\mathrm{H}_{2} \mathrm{O}$, but not to allow chemical re-equilibration with the groundmass melt (Blundy and Cashman 2005) (Fig. 8). This is consistent with the fact that the melt inclusions with the lowest $\mathrm{H}_{2} \mathrm{O}$ concentration are from the densest (dome)

samples, which have experienced a protracted cooling history at low pressure in the dome. When focussing only on the scoria and pumice samples, the general trend is for lower $\mathrm{SiO}_{2}$ and $\mathrm{K}_{2} \mathrm{O}$ melt inclusions to have higher $\mathrm{H}_{2} \mathrm{O}$ concentration than the higher $\mathrm{SiO}_{2}$ and $\mathrm{K}_{2} \mathrm{O}$ melt inclusions, which is consistent with vapour-saturated crystallisation in response to decompression (Fig. 8). Individual melt inclusion entrapment pressures, or the last pressures of reequilibration assuming vapour saturation, were calculated using the Papale $\mathrm{H}_{2} \mathrm{O}-\mathrm{CO}_{2}$ model (Papale et al. 2006), and using VolatileCalc1.1 (Newman and Lowenstern 2002), with both sets of calculations carried out at a temperature of $1,050{ }^{\circ} \mathrm{C}$ based upon the clinopyroxene-melt thermometry 
Fig. $8 \quad \mathrm{H}_{2} \mathrm{O}$ versus indicators of magmatic differentiation. a $\mathrm{SiO}_{2}$, b $\mathrm{K}_{2} \mathrm{O}$. Melt inclusions last equilibrated during decompression vapour-saturated crystallisation, with evidence that some melt inclusions ruptured during ascent
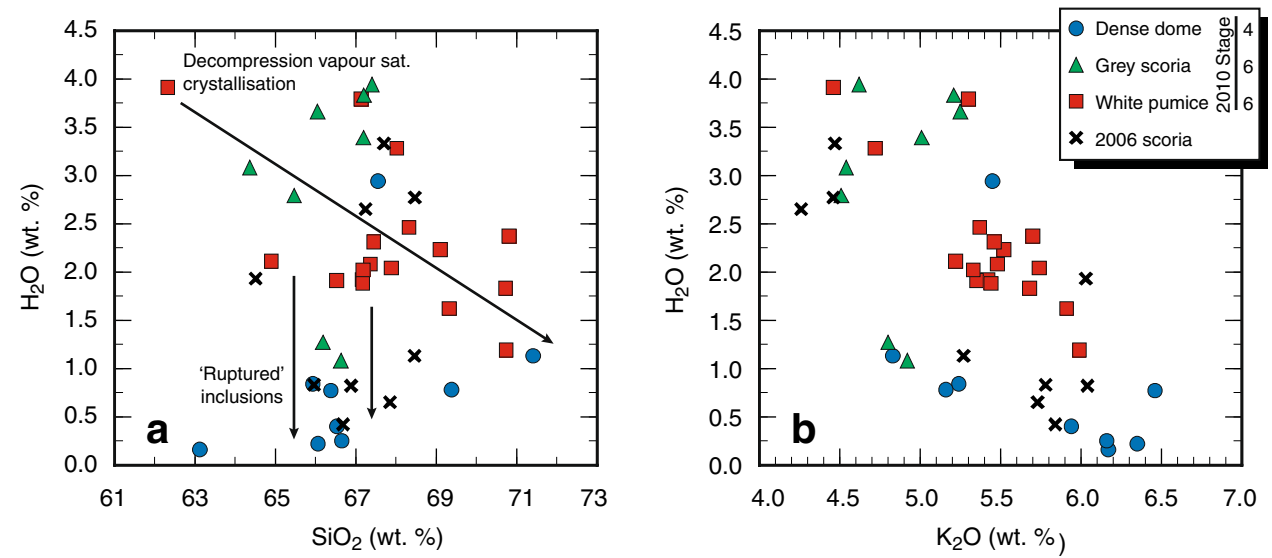

and previous thermometry of the 2010 products (Costa et al. 2013). Pressure values calculated with each model are similar. Minimum equilibration pressures, assuming volatile saturation, range from $<5$ to $265 \mathrm{MPa}$ using VolatileCalc. This pressure range is similar to that previously reported for Merapi pyroxene-hosted melt inclusions, which found the majority were trapped below $266 \mathrm{MPa}$ (Nadeau et al. 2013). However, as stated above, the lowest values probably reflect the fact that some melt inclusions have ruptured during ascent. To get a better estimate of the lowest entrapment pressure, the most evolved inclusion that sits on the decompression trend (Fig. 8) can be used, which suggests equilibration at $\sim 16 \mathrm{MPa}$. Therefore, melt inclusion equilibration depths range between $\sim 0.6$ and $9.7 \mathrm{~km}$.

In summary, there is an overlap between clinopyroxene crystallisation and melt inclusion equilibration at the lower end of the pressure range, although clinopyroxene crystallisation continues to greater depths, not reflected in the melt inclusion population. Clinopyroxene phenocrysts crystallised at depths up to $\sim 20 \mathrm{~km}$, with calculated minimum melt inclusion equilibration occurring between 0.6 and $9.7 \mathrm{~km}$. The clinopyroxene barometry results are in agreement with previous clinopyroxene barometry carried on recent eruptive products from Merapi (Gertisser 2001; Chadwick et al. 2013). Clinopyroxene crystallisation depths are also in accord with other geophysical and petrological evidence concerning the magmatic plumbing system of Merapi (e.g. Beauducel and Cornet 1999; Gertisser 2001; Costa et al. 2013). The calculated melt inclusion equilibration pressures complement those previously reported for Merapi (Nadeau et al. 2013). The discrepancy between the higher crystallisation pressure of the host clinopyroxene phenocrysts and the equilibration pressure of the melt inclusions can be explained in several ways. One possible explanation is that the melt was not vapour-saturated at the time of entrapment, therefore recording seemingly lower pressures than those of actual entrapment. This scenario is not considered likely as it is not consistent with the trends of vapour-saturated crystallisation (Fig. 8), nor with the presence of exsolved brine (see below), and is contradictory to previous evidence of volatile-saturated melt inclusions at Merapi (Nadeau et al. 2013). Another interpretation is that the inclusions are not primary but secondary, i.e. not trapped within hosts during initial crystallisation, but instead during subsequent partial dissolution, as previously observed for Merapi melt inclusions in amphibole and pyroxene hosts (Nadeau et al. 2013). However, there is no petrographic evidence for dissolution of the clinopyroxene host crystals that were analysed for this study. Therefore, the most likely explanation for the pressure difference is due to some melt inclusions re-equilibrating with the magma after initial entrapment. This is consistent with the vapoursaturated crystallisation trends, as shown in Fig. 8. The melt inclusions re-equilibrated over a range of pressures $<265 \mathrm{MPa}(\sim<10 \mathrm{~km})$, indicating either that there was enough time for re-equilibration during ascent, or, more likely, that magma was stored at this pressure range for a period of time before eruption. The fact that the maximum melt inclusion re-equilibration depth of $\sim 10 \mathrm{~km}$ matches that of previous melt inclusion studies (Nadeau et al. 2013), hints at the possibility that the magma has stalled at this depth. This depth is broadly consistent with geophysical (Beauducel and Cornet 1999; Ratdomopurbo and Poupinet 2000) and petrological (Chadwick et al. 2013; Costa et al. 2013) evidence for a magma storage region beneath Merapi. Seismic observations prior to the 2010 eruption detected heightened activity at the beginning of September 2010, with tremors at focal depths of $2.5-5 \mathrm{~km}$ depth until 17 October 2010, when activity became shallower and focal depths were $<1.5 \mathrm{~km}$ (Budi-Santoso et al. 2013; Jousset et al. 2013). This is consistent with ascent of a magma body over 1.5 months prior to eruption (BudiSantoso et al. 2013) with the depths correlating with those recorded by many of the melt inclusions and shallower crystallised clinopyroxenes. 
Degassing history $\left(\mathrm{H}_{2} \mathrm{O}\right.$ and $\left.\mathrm{CO}_{2}\right)$

Using VolatileCalc (at $1,050{ }^{\circ} \mathrm{C}$ ), trends for open- and closed-system degassing were calculated and compared to the Merapi melt inclusion data. In the open-system model, exsolved volatiles are removed from the system, whereas for closed-system runs, the exsolved vapour remains within the system, acting as a buffer on the remaining melt, including those volatiles that remain in solution in the depressurising magma. Closed-system models fit the data better than open-system ones, with the overall best fit having an initial starting point of $4.0 \mathrm{wt} \% \mathrm{H}_{2} \mathrm{O}, 1,000 \mathrm{ppm} \mathrm{CO}_{2}$ and $1 \%$ exsolved vapour (Fig. 3b). This closed-system trend is mainly defined by white pumice inclusions, indicating that closed-system degassing occurred prior to the sub-plinian explosive phase of the 2010 eruption, with the exsolved volatiles staying within the system, thus likely leading to increased overpressure and increased explosive activity. Inclusions from other stages of the eruption have re-equilibrated after the majority of the $\mathrm{CO}_{2}$ was degassed.

Evidence of pre- and syn-eruptive crystallisation and degassing processes from $\mathrm{F}, \mathrm{S}$ and $\mathrm{Cl}$ concentrations

Fluorine generally behaves as an incompatible element, although may be incorporated into certain minerals present in the Merapi mineral assemblage. For example, amphibole from the 2010 eruption has been found to include up to $0.6 \mathrm{wt} \% \mathrm{~F}$ and apatite contains $2.8-5.4 \mathrm{wt} \% \mathrm{~F}$ (Preece 2014). Fluorine concentrations in melt inclusions and groundmass glass (Fig. 4) are similar and within the typical range for subduction related magmas (Aiuppa et al. 2009 and references therein). The results are compatible with the fact that $\mathrm{F}$ is highly soluble in silicate melts (e.g. Carroll and Webster 1994), and generally partitions in favour of the melt relative to the vapour phase; therefore, it is often not significantly extracted from the melt by degassing (e.g. Balcone-Boissard et al. 2010).

Melt inclusions from the 2010 eruption contain a range of $\mathrm{S}$ from below the detection limit ( $100 \mathrm{ppm})$ up to $535 \mathrm{ppm}$. Total $\mathrm{SO}_{2}$ emissions for the entire 2010 eruption were calculated at $0.44 \mathrm{Tg}$, based on satellite observations (Surono et al. 2012). Assuming that the maximum S concentration in the melt inclusions (535 ppm) represents the pre-eruptive volatile content of the melt, and the $\mathrm{S}$ concentration in the groundmass glass $(<100 \mathrm{ppm})$ indicates the post-eruptive volatile content, it is possible to calculate the mass and volume of magma needed to produce the $0.44 \mathrm{Tg}$ of $\mathrm{SO}_{2}$ that were emitted during the eruption (Self et al. 2004). The approximate phenocryst content of the 2010 dome samples is $\sim 40 \mathrm{vol} \%$, and taking into account the fraction of felsic to mafic minerals in the rocks, the proportion of phenocrysts is $\sim 45 \mathrm{wt} \%$ (i.e. the melt or groundmass occupies $55 \mathrm{wt} \%)$. Results indicate that the mass of degassing magma in the 2010 eruption was $9.2 \times 10^{11} \mathrm{~kg}$, and taking into account a melt density of $2,550 \mathrm{~kg} \mathrm{~m}^{-3}$, calculated from the composition of a typical dome clast using the software Pele (Boudreau 1999), the corresponding melt volume is $0.36 \mathrm{~km}^{3}$. In comparison, it has been estimated that between 0.03 and $0.06 \mathrm{~km}^{3}$ of magma (DRE) was erupted during the 2010 eruption (Surono et al. 2012), an order of magnitude less than the calculated total volume of degassing melt in the system, indicating either that a large proportion of melt did not erupt and remained in the system or that extra sources of volatiles (S) contributed to the volatile budget of the eruption.

The $\mathrm{Cl}$ content of the groundmass glass is generally lower than the concentration in the melt inclusion population, indicating $\mathrm{Cl}$ exsolution at low pressures during syneruptive degassing (Fig. 9). The $\mathrm{Cl}$ concentrations in the melt inclusions are similar to other arc magmas (Aiuppa et al. 2009 and references therein). Melt inclusion $\mathrm{Cl}$ concentrations range between 2,060 and 5,130 ppm, although nearly $90 \%$ of the data in this study range between 2,400 and 3,400 ppm (Fig. 9), with the higher concentrations only observed in white pumice melt inclusions. The simplest explanation for a relatively limited range of $\mathrm{Cl}$ in the melt inclusions, regardless of variations in $\mathrm{H}_{2} \mathrm{O}$, could be that the magma underwent decompression degassing with preferential loss of $\mathrm{H}_{2} \mathrm{O}$ and no apparent loss of $\mathrm{Cl}$ (Webster et al. 2010; Mann et al. 2013). However, an alternative

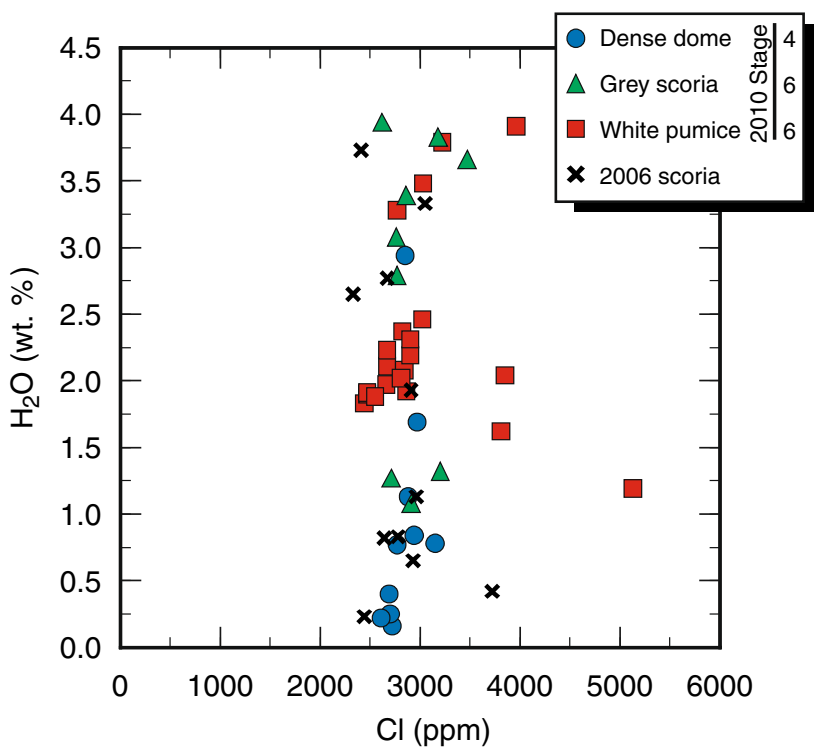

Fig. 9 Concentration of $\mathrm{Cl}$ versus $\mathrm{H}_{2} \mathrm{O}$ in melt inclusions. Melt inclusions from the 2010 samples as well as from the 2006 scoriaceous dome show constant $\mathrm{Cl}$ concentrations with variable $\mathrm{H}_{2} \mathrm{O}$ contents, providing evidence that the $\mathrm{Cl}$ concentration in the melt was "buffered" by a hydrochloride phase. The only inclusions that deviate to higher $\mathrm{Cl}$ concentrations are several from the white pumice 
explanation is that the silicate melt was in equilibrium with a magmatic hydrosaline chloride liquid \pm vapour (e.g. Lowenstern 1994; Shinohara 1994; Webster 1997, 2004). Chlorine concentrations in the silicate melt are "buffered" and so remain constant as $\mathrm{Cl}$ reaches its solubility limit in equilibrium with the liquid phase(s). Similar indirect geochemical evidence for the presence of a hydrosaline chloride liquid from melt inclusion data has been reported at Mount Hood (Koleszar et al. 2012), the Bandelier Tuff, Valles Caldera (Stix and Layne 1996) and Vesuvius (Signorelli et al. 1999; Fulignati and Marianelli 2007). The $\mathrm{Cl}$ concentrations in the Merapi melt inclusions are similar to saturation values for felsic melts determined experimentally (e.g. Métrich and Rutherford 1992; Webster 1997) as well as the values recorded in natural felsic melt inclusions interpreted to have been in equilibrium with a Cl-rich liquid (Stix and Layne 1996; Koleszar et al. 2012). This evidence for the presence of a saline liquid or "brine" phase is corroborated by the Li and B data (see section below).

\section{Li and B enrichment}

Lithium is enriched in melt inclusions from the 2010 dense dome material and the 2006 scoria, which contain relatively low concentrations of $\mathrm{H}_{2} \mathrm{O}$. It displays an L-shaped, divergent trend when plotted against $\mathrm{H}_{2} \mathrm{O}$ and $\mathrm{Cl}$ and displays no correlation with $\mathrm{SiO}_{2}$ or $\mathrm{K}_{2} \mathrm{O}$ (Fig. 5). Enrichment of $\mathrm{B}$ occurs in melt inclusions from white pumice samples, which have mid-range $\mathrm{H}_{2} \mathrm{O}$ content, with variable $\mathrm{Cl}$, including elevated contents. These contrasting features indicate that $\mathrm{Li}$ and $\mathrm{B}$ enrichment are produced by different processes, corroborated by the decoupled relationship of $\mathrm{Li}$ versus B (Fig. 5) as well as the fact that enrichment occurs in distinct and separate lithological types.

Lithium-enriched inclusions, only detected in 2010 dense dome samples and 2006 scoriaceous dome samples, have last equilibrated at near-surface depths, with the maximum $\mathrm{Li}$ enrichment in 2010 inclusions at $\mathrm{P}_{\mathrm{H}_{2} \mathrm{O}}=14.5 \mathrm{MPa}$ (0.5 km depth) and $\mathrm{P}_{\mathrm{H}_{2} \mathrm{O}}=36.5 \mathrm{MPa}(1.3 \mathrm{~km}$ depth) for maximum $\mathrm{Li}$ in 2006 . This implies that $\mathrm{Li}$ enrichment is a pressure-mediated process. Lithium enrichment in early erupted dome samples, detected in melt inclusions equilibrated at specific $\mathrm{H}_{2} \mathrm{O}$ concentrations, has also been noted at Mount St. Helens (Berlo et al. 2004; Blundy et al. 2008) and at Shiveluch (Humphreys et al. 2008). This has been attributed to pre-eruptive, vapour-mediated transfer of $\mathrm{Li}$, derived from deeper within the magma transport system. Alternatively, Li-rich inclusions may be produced via re-equilibration with a Li-rich brine phase (Kent et al. 2007). An alkali-rich aqueous vapour can be produced via the degassing of an $\mathrm{H}_{2} \mathrm{O}$-saturated magma body. Buoyant upward migration of this vapour results in its exsolution to produce two phases: a dense alkali-rich brine and a lower density $\mathrm{H}_{2} \mathrm{O}$-rich vapour (Kent et al. 2007). The lower density $\mathrm{H}_{2} \mathrm{O}$-rich vapour is subsequently lost via degassing and the alkali-rich brine re-equilibrates with the melt, resulting in Li-enriched melt inclusions. Gas measurements and mass balance models (Nadeau et al. 2013) also predict the presence of a brine phase below Merapi and suggests that the volatile phase is exsolved as a single supercritical fluid below at least $5 \mathrm{~km}$ depth and exsolves directly as vapour + brine phases above this critical depth. In the Merapi melt inclusions, the Li-enriched inclusions all contain similar $\mathrm{Cl}$ concentrations (Fig. 5), further indicating that Li-enrichment occurred during "buffering" of the melt $\mathrm{Cl}$ concentrations, related to equilibration of the melt with the brine phase. The inflexed trend in $\mathrm{SiO}_{2}$ versus $\mathrm{Na}_{2} \mathrm{O}$, with decreasing $\mathrm{Na}_{2} \mathrm{O}$ in the groundmass glass (Fig. 2), may also be attributed to Na partitioning into the exsolving fluid phase during volatile-saturated crystallisation (Blundy et al. 2008).

The behaviour of B in magmatic and hydrothermal systems is complex and previous studies have reached differing conclusions as to whether B partitions preferentially into the melt or into the aqueous phase(s) (e.g. Pichavant 1981; Webster et al. 1989; Heinrich et al. 1999; Hervig et al. 2002; Schatz et al. 2004). Recent studies of natural samples have shown that transient B depletion and enrichment may be related to changing degassing regimes (Menard et al. 2013; Vlastélic et al. 2013) or alternatively enrichment may occur due to crystallisation and magmatic fractionation (Wright et al. 2012). In the Merapi melt inclusions, the correlation of $\mathrm{B}$ with $\mathrm{SiO}_{2}$ indicates that $\mathrm{B}$ behaves as an incompatible element. The enrichment of B with crystallisation shows that B remained in the melt, suggesting a low vapour-melt partition coefficient, as also observed, for example, in melt inclusions from Crater Lake (Wright et al. 2012). One possible control on the partitioning behaviour of $\mathrm{B}$ is the $\mathrm{NaCl}$ content of the brine and vapour, as higher B solubility is expected in melts which are in equilibrium with saline brines (Schatz et al. 2004). Therefore, the enrichment of B in the Merapi melt may be due to the presence of the brine which acted to increase B solubility in the melt, allowing the incompatible B to become enriched in the melt during crystallisation.

Driving forces behind the 2010 eruption and comparison with the 2006 eruption

In many respects, the contrasting behaviour of the 2010 and 2006 eruptions is not reflected in the investigated eruptive products. Whole rock, melt inclusion and groundmass compositions are all similar in terms of major elements and volatile $\left(\mathrm{H}_{2} \mathrm{O}, \mathrm{CO}_{2}, \mathrm{~F}, \mathrm{Cl}\right.$ and $\left.\mathrm{S}\right)$ concentrations are predominantly similar also. Whole-rock compositions are similar for the 2010 and 2006 erupted lavas and remained 
nearly constant throughout the duration of each eruption. This indicates that bulk magmatic composition cannot be a major factor in the change in behaviour between the two basaltic andesite eruptions. However, there are some differences between the products, particularly in melt inclusions originating from the white pumice, which is unique to the 2010 eruption. The white pumice clasts show numerous distinctive features when compared to other 2010 samples and reveal evidence of an increase in deep magma supply, highlighted by an abundance of clinopyroxene phenocrysts that crystallised at $>11-15 \mathrm{~km}$ depth $(>300-400 \mathrm{MPa})$ (Fig. 10). This is in agreement with other petrological and monitoring data (Surono et al. 2012; Costa et al. 2013; Jousset et al. 2013). Increasing fumarole gas temperatures and ratios of $\mathrm{CO}_{2} / \mathrm{SO}_{2}, \mathrm{CO}_{2} / \mathrm{HCl}$ and $\mathrm{CO}_{2} / \mathrm{H}_{2} \mathrm{O}$ in months prior to the 2010 eruption, were interpreted to be due to the degassing of a deep magmatic source (Surono et al. 2012). Costa et al. (2013) proposed that the 2010 eruption was preceded by an influx of deeper, hotter, more volatilerich magma that was up to 10 times more voluminous than that in 2006. Melt inclusions from grey scoria and white pumice clasts also preserve evidence of closed-system conditions during ascent, with higher $\mathrm{H}_{2} \mathrm{O}$ concentrations compared to the dome melt inclusions. Volatile concentrations in melt inclusions from white pumice clasts fit with

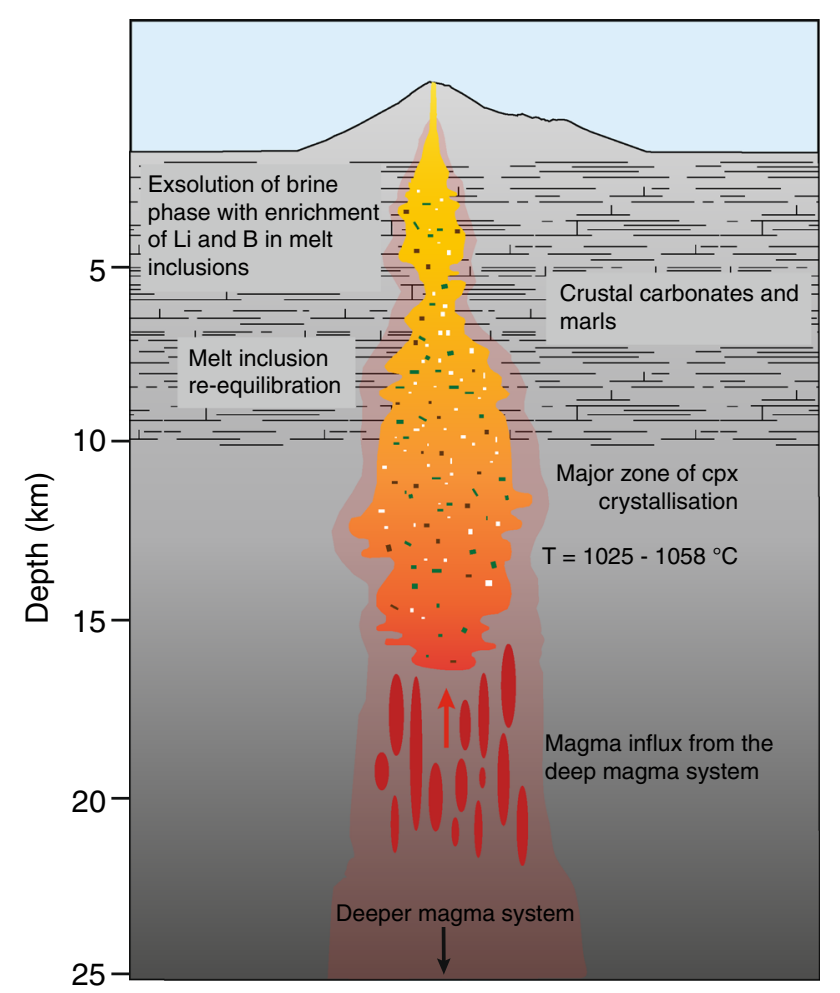

Fig. 10 Schematic diagram of the Merapi magmatic plumbing system as revealed by 2010 and 2006 melt inclusions and clinopyroxene host phenocrysts modelled concentrations predicted for a closed-system in equilibrium with $1 \%$ exsolved volatiles. A deep influx of magma would have caused increased overpressure and faster magma ascent. Closed-system degassing and fast magma ascent rates, as a result of the deep influx of magma, were key driving forces behind the explosive nature of the 2010 eruption. Closed-system degassing likely sustained explosive behaviour, generating a subplinian convective column, which collapsed to produce the scoria- and pumice-rich PDCs during Stage 6 of the 2010 eruption. The continuous range of melt inclusion re-equilibration at depths between 9.7 and $0.6 \mathrm{~km}$ suggests that the melt region, at these depths at least, is interconnected and not formed by isolated chambers (Fig. 10).

Silicate melt from early-erupted products (i.e. dome clasts) of both 2010 and 2006 was saturated in $\mathrm{Cl}$, preserving evidence of the presence of a hydrosaline fluid or "brine" phase within the magmatic system prior to each eruption. Further evidence for this comes from the fact that these same melt inclusions are enriched in $\mathrm{Li}$, indicating similar shallow-level processes operating prior to the dome-building stage of each eruption, in agreement with Nadeau et al. (2013). White pumice melt inclusions are enriched in B, which was stabilised in the melt rather than degassing, due to the presence of the brine phase. It acted as an incompatible element, thereby becoming enriched in the melt during fractional crystallisation.

Although the melt inclusions and their clinopyroxene hosts in this study have shed light on the magmatic system and magmatic contributions to the eruptive behaviour of Merapi during 2010 and 2006, other factors are likely to have contributed to the eruptive dynamics. Shallowlevel degassing and crystallisation of microlites, likely not reflected in melt inclusion data, have been associated with increasing overpressure, changing degassing regimes and increasing explosivity in 2010 (Preece 2014). Previous workers (e.g. Chadwick et al. 2007; Deegan et al. 2010; Troll et al. 2012, 2013; Borisova et al. 2013) have proposed that $\mathrm{CO}_{2}$ liberation via crustal carbonate assimilation has the potential to sustain and intensify eruptions at Merapi. Monitoring data of the 2010 eruption indicate large $\mathrm{CO}_{2}$ emissions prior to the 2010 eruption (Surono et al. 2012), and previous melt inclusions have been interpreted to reflect $\mathrm{CO}_{2}$ fluxing at Merapi (Nadeau et al. 2013). However, in contrast to previous studies (Nadeau et al. 2013), the $\mathrm{CO}_{2}$ data and trends collected during this study cannot be reliably attributed to $\mathrm{CO}_{2}$ fluxing due to the apparent heterogeneous distribution of $\mathrm{CO}_{2}$ in some of the melt inclusions. The peak of the 2010 eruption was preceded by a regional tectonic earthquake. On 4 November 2010, a M4.2 earthquake occurred $\sim 200 \mathrm{~km}$ south of Merapi, at 23:56 local time, just prior to the climactic phase of 5 November. Several authors have suggested a probable 
connection between regional seismic activity and the intensification of eruptive activity at Merapi (e.g. Walter et al. 2007; Surono et al. 2012; Troll et al. 2012; Jousset et al. 2013). Although Jousset et al. (2013) stress that the main factor causing over-pressurisation at Merapi in 2010 was related to magmatic influx and ascent, it is possible that with the magmatic system already at a critical pressurised stage, a small external force can affect the gas phase, promoting rapid degassing, fragmentation and eruption of an already unstable system (e.g. Brodsky et al. 1998; Davis et al. 2007; Walter et al., 2007).

The melt inclusions and clinopyroxene hosts shed light on the magmatic plumbing system prior to the two most recent eruptions of Merapi and reveal an influx of deeper magma during the 2010 eruption, which was a key factor in determining the eruptive dynamics of the cataclysmic 2010 eruption. However, in addition to this, the influence of factors such as shallow-level degassing and crystallisation feedback mechanisms, carbonate assimilation and regional earthquakes should not be ignored.

\section{Conclusion}

Using melt inclusions and their clinopyroxene hosts, this study has revealed information about the pre-2010 and pre-2006 Merapi magma system, and key factors that contributed to the cataclysmic events of 2010. Despite the contrasting eruptive behaviour, the 2010 and 2006 eruptive products are remarkably similar in terms of bulk rock and melt inclusion major element concentrations. In addition, volatile contents of both melt inclusions and groundmass glass are also similar. The continuous range of melt inclusion re-equilibration at depths $<10 \mathrm{~km}$ suggests that the melt region, at these depths at least, is interconnected and not formed by isolated chambers. Dome fragments from both eruptions reveal evidence of an exsolved brine phase prior to eruption, with melt inclusions from these clasts enriched in $\mathrm{Li}$ and with "buffered" $\mathrm{Cl}$ concentrations. In addition, melt inclusions from the 2010 white pumice formed during explosive activity and which equilibrated during closed-system degassing, are enriched in B, which was stabilised in the melt due to the presence of the brine phase. Clinopyroxene host phenocrysts from the white pumice crystallised at greater depths (up to $20 \mathrm{~km}$ ) compared to those erupted during other stages of the 2010 eruption or those from 2006. The transition from effusive dome-forming to explosive (sub-plinian) behaviour during the 2010 eruption was triggered by an influx of magma from depth which increased the overpressure and "overwhelmed" the system. This was further increased by a closed-system degassing regime, with exsolved volatiles staying in the system. Careful melt inclusion analysis, utilising various complementary techniques including SIMS and ATR micro-FTIR revealed heterogeneous $\mathrm{CO}_{2}$ distribution in some melt inclusions, thought to have formed during post-entrapment modifications, and highlights the need for caution in melt inclusion studies. This work emphasizes the influence of magmatic flux, and magmatic degassing in controlling the eruptive style at Merapi volcano. Variations in these factors will serve to modulate future activity, controlling whether eruptions will be effusive and dome-forming or more explosive.

Acknowledgments We are grateful to staff at the Edinburgh Ion Microprobe Facility, especially to Cees-Jan de Hoog, for technical assistance during SIMS analysis as well as valuable suggestions regarding data interpretation, and to Richard Hinton for advice. Many thanks to Jake Lowenstern (US Geological Survey, Menlo Park) for kindly carrying out ATR micro-FTIR analysis, as well as for useful discussions. Thanks go to Andy Tindle (The Open University), Chiara Petrone and Iris Buisman (University of Cambridge) for help with electron microprobe analyses, as well as to Bertrand Lézé (University of East Anglia) for technical support with the SEM. Peter Greatbatch and David Wilde (Keele University) are acknowledged for assistance in polishing resin blocks. Adam Jeffery (Keele University) is acknowledged and thanked for valuable advice regarding thermobarometric techniques. We thank Jean-Christophe Komorowski (Institut de Physique du Globe de Paris, Université Paris Diderot) for kindly sharing a base map for Fig. 1 and for thought-provoking discussions in the field. Sylvain Charbonnier and Aurélie Germa (University of South Florida) are thanked for their assistance in collecting samples in the field. We appreciate the constructive reviews by Val Troll and an anonymous reviewer, as well the Editor, Jon Blundy, whose comments helped to clarify the paper. This work has been supported by the Natural Environment Research Council (NERC) through Urgency grant NE/I029927/1, as well as a NERC studentship to KP (grant number NE/H524506/1).

Open Access This article is distributed under the terms of the Creative Commons Attribution License which permits any use, distribution, and reproduction in any medium, provided the original author(s) and the source are credited.

\section{References}

Aiuppa A, Baker DR, Webster JD (2009) Halogens in volcanic systems. Chem Geol 263:1-18

Allard P, Métrich N, Sabroux J-C (2011) Volatile and magma supply to standard eruptive activity at Merapi volcano, Indonesia. Geophys Res Abstr 13:EGU2011-13522

Andreastuti SD, Alloway BV, Smith IEM (2000) A detailed tephrostratigraphic framework at Merapi volcano, Central Java, Indonesia: implications for eruption predictions and hazards assessment. J Volcanol Geoth Res 100:51-67

Atlas ZD, Dixon JE, Sen G, Finny M, Lillian A, Pozzo MD (2006) Melt inclusions from Volcán Popocatépetl and Volcán de Colima, Mexico: melt evolution due to vapor-saturated crystallization during ascent. J Volcanol Geoth Res 153:221-240

Baker DR (2008) The fidelity of melt inclusions as a record of melt composition. Contrib Miner Petrol 156:377-395

Balcone-Boissard H, Villemant B, Boudon G (2010) Behaviour of halogens during the degassing of felsic magmas. Geochem Geophys Geosyst 11:Q09005 
Beauducel F, Cornet FH (1999) Collection and three- dimensional modeling of GPS and tilt data at Merapi volcano, Java. J Geophys Res 104:725-736

Berlo K, Blundy J, Turner S, Cashman K, Hawkesworth C, Black S (2004) Geochemical precursors to volcanic activity at Mount St. Helens, USA. Science 306:1167-1169

Berlo K, Stix J, Roggensack K, Ghaleb B (2012) A tale of two magmas, Fuego, Guatemala. Bull Volc 74:377-390

Blundy J, Cashman K (2005) Rapid decompression-driven crystallisation recorded by melt inclusions from Mount St. Helens volcano. Geology 33:793-796

Blundy J, Cashman K (2008) Petrologic reconstruction of magmatic system variables and processes. Rev Mineral Petrol 69:179-239

Blundy J, Cashman KV, Berlo K (2008) Evolving magma storage conditions beneath Mount St. Helens inferred from chemical variations in melt inclusions from the 1980-1986 and current (2004-2006) eruptions. In: Sherrod DR, Scott WE, Stauffer PH (Eds) A volcano rekindled: the renewed eruption of Mount St. Helens, 2004-2006. US Geol Surv Prof Pap 1750, pp. 755-790

Blundy J, Cashman KV, Rust A, Witham F (2010) A case for $\mathrm{CO}_{2}-$ rich arc magmas. Earth Planet Sci Lett 290:289-301

Borisova AY, Martel C, Gouy S, Pratomo I, Sumarti S, Toutain J-P, Bindeman IN, de Parseval P, Metaxian J-P, Surono (2013) Highly explosive 2010 Merapi eruption: evidence for shallowlevel crustal assimilation and hybrid fluid. J Volcanol Geoth Res 261:193-208

Boudreau AE (1999) PELE-a version of the MELTS software program for the PC platform. Comput Geosci 25:201-203

Brodsky EE, Sturtevant B, Kanamori H (1998) Earthquakes, volcanoes, and rectified diffusion. J Geophys Res Solid Earth 103:23827-23838

Bucholz CE, Gaetani GA, Behn MD, Shimizu N (2013) Post-entrapment modification of volatiles and oxygen fugacity in olivinehosted melt inclusions. Earth Planet Sci Lett 374:145-155

Budi-Santoso A, Lesage P, Dwiyono S, Sumarti S, Surono, Subandriyo, Jousset P, Metaxian J-P (2013) Analysis of the seismic activity associated with the 2010 eruption of Merapi Volcano, Java. J Volcanol Geoth Res 261:153-170

Camus G, Gourgoud A, Mossand-Berthommier P-C, Vincent P-M (2000) Merapi (Central Java, Indonesia): an outline of the structural and magmatological evolution, with special emphasis to the major pyroclastic events. J Volcanol Geoth Res 100:139-163

Carroll MR, Webster JD (1994) Solubilities of sulfur, noble gases, nitrogen, chlorine and fluorine in magmas. In: Carroll MR, Holloway JR (eds) Volatiles in magmas. Rev Mineral Geochem 30:231-279

Chadwick JP, Troll VR, Ginibre C, Morgan D, Gertisser R, Waight TE, Davidson JP (2007) Carbonate assimilation at Merapi Volcano, Java, Indonesia: insights from crystal isotope stratigraphy. J Petrol 48:1793-1812

Chadwick JP, Troll VR, Waight TE, van der Zwan FM, Schwarzkopf LM (2013) Petrology and geochemistry of igneous inclusions in recent Merapi deposits: a window into the sub-volcanic plumbing system. Contrib Miner Petrol 165:259-282

Charbonnier SJ, Gertisser R (2008) Field observations and surface characteristics of pristine block-and-ash flow deposits from the 2006 eruption of Merapi volcano, Java, Indonesia. J Volcanol Geoth Res 177:971-982

Charbonnier SJ, Germa AM, Connor CB, Gertisser R, Preece K, Komorowski J-C, Lavigne F, Dixon TH, Connor LJ (2013) Evaluation of the impact of the 2010 pyroclastic density currents at Merapi volcano from high-resolution satellite imagery analysis, field investigations and numerical simulations. J Volcanol Geoth Res 261:295-315
Chen Y, Provost A, Schiano P, Cluzel N (2011) The rate of water loss from olivine-hosted melt inclusions. Contrib Miner Petrol 162:625-636

Clocchiatti R, Joron JL, Kerinec F, Treuil M (1982) Quelques données préliminaires sur la lave du dôme actuel du volcan Mérapi (Java, Indonésie) et sur ses enclaves. CR Acad Sci Paris 295:817-822

Costa F, Andreastuti S, de Maisonneuve CB, Pallister JS (2013) Petrological insights into the storage conditions, and magmatic processes that yielded the centennial 2010 Merapi explosive eruption. J Volcanol Geoth Res 261:209-235

Dahren B, Troll VR, Andersson UB, Chadwick JP, Gardner MF, Jaxybulatov K, Koulakov I (2012) Magma plumbing beneath Anak Krakatau volcano, Indonesia: evidence for multiple magma storage regions. Contrib Miner Petrol 163:631-651

Danyushevsky LV, Plechov P (2011) Petrolog 3: integrated software for modeling crystallization processes. Geochem Geophys Geosyst 12:Q07021

Danyushevsky LV, McNeill AW, Sobolev AV (2002) Experimental and petrological studies of melt inclusions in phenocrysts from mantle-derived magmas: an overview of techniques, advantages and complications. Chem Geol 183:5-24

Davis M, Koenders MA, Petford N (2007) Vibro-agitation of chambered magma. J Volcanol Geoth Res 167:24-36

Deegan FM, Troll VR, Freda C, Misiti V, Chadwick JP, McLeod CL, Davidson JP (2010) Magma-carbonate interaction processes and associated $\mathrm{CO}_{2}$ release at Merapi volcano, Indonesia: insights from experimental petrology. J Petrol 51:1027-1051

Eichelberger JC (1995) Silicic volcanism: ascent of viscous magmas from crustal reservoirs. Annu Rev Earth Planet Sci 23:41-63

Eichelberger JC, Carrigan CR, Westrich HR, Price RH (1986) Nonexplosive silicic volcanism. Nature 323:598-602

Fulignati P, Marianelli P (2007) Tracing volatile exsolution within the $472 \mathrm{AD}$ "Pollena" magma chamber of Vesuvius (Italy) from melt inclusion investigation. J Volcanol Geoth Res 161:289-302

Gaetani GA, O'Leary JA, Shimizu N, Bucholz CE, Newville M (2012) Rapid reequilibration of $\mathrm{H}_{2} \mathrm{O}$ and oxygen fugacity in olivine-hosted melt inclusions. Geology 40:915-918

Gauthier P-J, Condomines M (1999) ${ }^{210} \mathrm{~Pb}^{226} \mathrm{Ra}$ radioactive disequilibria in recent lavas and radon degassing: inferences on magma chamber dynamics at Stromboli and Merapi volcanoes. Earth Planet Sci Lett 172:111-126

Gertisser R (2001) Gunung Merapi (Java, Indonesien): Eruptionsgeschichte und Magmatische Evolution eines Hochrisiko-Vulkans. $\mathrm{Ph}$.D. Thesis, Universität Freiburg, Germany

Gertisser R, Keller J (2003) Trace element and Sr, Nd, Pb, and O isotope variations in medium- $\mathrm{K}$ and high- $\mathrm{K}$ volcanic rocks from Merapi volcano, Central Java, Indonesia: evidence for the involvement of subducted sediments in Sunda Arc magma genesis. J Petrol 44:475-489

Gertisser R, Charbonnier SJ, Troll VR, Keller J, Preece K, Chadwick JP, Barclay J, Herd RA (2011) Merapi (Java, Indonesia): anatomy of a killer volcano. Geol Today 27:57-62

Gertisser R, Charbonnier SJ, Keller J, Quidelleur X (2012a) The geological evolution of Merapi volcano, Central Java, Indonesia. Bull Volc 74:1213-1233

Gertisser R, Cassidy NJ, Charbonnier SJ, Nuzzo L, Preece K (2012b) Overbank block-and-ash flow deposits and the impact of valleyderived, unconfined flows on populated areas at Merapi volcano, Java, Indonesia. Nat Hazards 60:623-648

Gonnermann HM, Manga M (2005) Nonequilibrium magma degassing: results from modeling of the ca. 1340 A.D. eruption of Mono Craters, California. Earth Planet Sci Lett 238:1-16

Hamilton W (1979) Tectonics of the Indonesian region. US Geol Surv Prof Pap 1078:1-345 
Hammer JE, Cashman KV, Voight B (2000) Magmatic processes revealed by textural and compositional trends in Merapi dome lavas. J Volcanol Geoth Res 100:165-192

Hauri E, Wang J, Dixon JE, King PL, Mandeville C, Newman S (2002) SIMS analysis of volatiles in silicate glasses 1. Calibration, matrix effects and comparisons with FTIR. Chem Geol 183:99-114

Heinrich CA, Günther D, Audétat A, Ulrich T, Frischknecht R (1999) Metal fractionation between magmatic brine and vapor, determined by microanalysis of fluid inclusions. Geology 27:755-758

Hercule S, Ingrin J (1999) Hydrogen in diopside: diffusion, kinetics of extraction-incorporation, and solubility. Am Mineral 84:1577-1587

Hervig RL, Moore GM, Williams LB, Peacock SM, Holloway JR, Roggensack K (2002) Isotopic and elemental partitioning of boron between hydrous fluid and silicate melt. Am Mineral 87:769-774

Holloway JR, Blank JG (1994) Application of experimental results to $\mathrm{C}-\mathrm{O}-\mathrm{H}$ species in natural melts. Rev Mineral Geochem 30:187-230

Humphreys MCS, Blundy JD, Sparks RSJ (2008) Shallow-level decompression crystallisation and deep magma supply at Shiveluch Volcano. Contrib Miner Petrol 155:45-61

Jaupart C, Allègre C (1991) Gas content, eruption rate and instabilities of eruption regime in silicic volcanoes. Earth Planet Sci Lett 102:413-429

Jeffery A, Gertisser R, Troll VR, Jolis EM, Dahren B, Harris C, Tindle AG, Preece K, O’Driscoll B, Humaida H, Chadwick JP (2013) The pre-eruptive magma plumbing system of the 2007-2008 dome-forming eruption of Kelut volcano, East Java, Indonesia. Contrib Miner Petrol 166:275-308

Johnson ER, Wallace PJ, Cashman KV, Delgado Granados H, Kent AJR (2008) Magmatic volatile contents and degassing-induced crystallization at Volcán Jorullo, Mexico: implications for melt evolution and the plumbing systems of monogenetic volcanoes. Earth Planet Sci Lett 269:478-487

Jousset P, Budi-Santoso A, Jolly AD, Boichu M, Surono I, Dwiyono S, Sumarti A, Hidayati S, Thierry P (2013) Signs of magma ascent in LP and VLP seismic events and link to degassing: an example from the 2010 explosive eruption at Merapi volcano, Indonesia. Indonesia. J Volcanol Geoth Res 261:171-192

Kent AJR (2008) Melt inclusions in basaltic and related volcanic rocks. In: Putirka KD, Tepley III FJ (eds) Minerals, inclusions and volcanic processes. Rev Mineral Petrol 69:273-332

Kent AJR, Blundy J, Cashman KV, Cooper KM, Donnelly C, Pallister JS, Reagan M, Rowe MC, Thornber CR (2007) Vapor transfer prior to the October 2004 eruption of Mount St. Helens, Washington. Geology 35:231-234

Koleszar AM, Kent AJR, Wallace PJ, Scott WE (2012) Controls on long-term explosivity at andesitic arc volcanoes: insights from Mount Hood, Oregon. J Volcanol Geoth Res 219-220:1-14

Komorowski JC, Jenkins S, Baxter PJ, Picquout A, Lavigne F, Charbonnier S, Gertisser R, Preece K, Cholik N, Budi-Santoso A, Surono (2013) Paroxysmal dome explosion during the Merapi 2010 eruption: processes and facies relationships of associated high-energy pyroclastic density currents. J Volcanol Geoth Res 261:260-294

Le Cloarec M-F, Gauthier P-J (2003) Merapi Volcano, Central Java, Indonesia: a case study of radionuclide behavior in volcanic gases and its implications for magma dynamics at andesitic volcanoes. J Geophys Res 108(B5):2243

Le Guern F, Gerlach TM, Nohl A (1982) Field gas chromatograph analyses of gases from a glowing dome at Merapi volcano, Java, Indonesia, 1977, 1978, 1979. J Volcanol Geoth Res 14:223-245

Le Pennec J-L, Hermitte D, Dana I, Pezard P, Coulon C, Cochemé J-J, Mulyadi E, Ollagnier F, Revest C (2001) Electrical conductivity and pore-space topology of Merapi lavas: implications for the degassing of porphyritic andesite magmas. Geophys Res Lett 28:4283-4286

Lloyd A, Plank T, Ruprecht P, Hauri E, Rose W (2013) Volatile loss from melt inclusions in pyroclasts of differing sizes. Contrib Miner Petrol 165:129-153

Lowenstern JB (1994) Chlorine, fluid immiscibility and degassing in peralkaline magmas from Pantelleria, Italy. Am Mineral 79:353-369

Lowenstern JB (1995) Applications of silicate-melt inclusions to the study of magmatic volatiles. In: Thompson JFH (ed) Magmas, fluids and ore deposits. Mineral Assoc Can Short Course 23:71-99

Lowenstern JB (2003) Melt inclusions come of age: volatiles, volcanoes, and Sorby's legacy. In: De Vivo B, Bodnar RJ (eds) Melt inclusions in volcanic systems: methods, applications and problems. Developments in Volcanology, vol 5. Elsevier Press, Amsterdam, pp 1-22

Lowenstern JB, Pitcher BW (2013) Analysis of $\mathrm{H}_{2} \mathrm{O}$ in silicate glass using attenuated total reflectance (ATR) micro-FTIR spectroscopy. Am Mineral 98:1660-1668

Lube G, Cronin SJ, Thouret J-C, Surono (2011) Kinematic characteristics of pyroclastic density currents at Merapi and controls on their avulsion from natural and engineered channels. Geol Soc Am Bull 123:1127-1140

Mann CP, Wallace PJ, Stix J (2013) Phenocryst-hosted melt inclusions record stalling of magma during ascent in the conduit and upper magma reservoir prior to vulcanian explosions, Soufrière Hills volcano, Montserrat, West Indies. Bull Volc 75:1-16

Martel C, Pichavant M, Bourdier J-L, Traineau H, Holtz F, Scaillet B (1998) Magma storage conditions and control of eruption regime in silicic volcanoes: experimental evidence from Mt. Pelée. Earth Planet Sci Lett 156:89-99

Melnik O, Sparks RSJ (1999) Nonlinear dynamics of lava dome extrusion. Nature 402:37-41

Melnik O, Sparks RSJ (2005) Controls on conduit flow dynamics during lava dome building eruptions. J Geophys Res 110:B02209

Menard G, Vlastélic I, Rose-Koga EF, Piro J-L, Pin C (2013) Precise and accurate determination of boron concentration in silicate rocks by direct isotope dilution ICP-MS: insights into the $\mathrm{B}$ budget of the mantle and B behavior in magmatic systems. Chem Geol 354:139-149

Métrich N, Rutherford MJ (1992) Experimental study of chlorine behaviour in hydrous silicic melts. Geochim Cosmochim Acta 56:607-616

Murphy MD, Sparks RSJ, Barclay J, Carroll MR, Brewer TS (2000) Remobilization of andesite magma by intrusion of mafic magma at the Soufriere Hills Volcano, Montserrat, West Indies. J Petrol 41:21-42

Nadeau O, Williams-Jones AE, Stix J (2010) Sulphide magma as a source of metals in arc-related magmatic hydrothermal ore fluids. Nat Geosci 3:501-505

Nadeau O, Williams-Jones AE, Stix J (2013) Magmatic-hydrothermal evolution and devolatilization beneath Merapi volcano, Indonesia. J Volcanol Geoth Res 261:50-68

Newhall CG, Bronto S, Alloway B, Banks NG, Bahar I, del Marmol MA, Hadisantono RD, Holcomb RT, McGeehin J, Miksic JN, Rubin M, Sayudi SD, Sukhyar R, Andreastuti S, Tilling RI, Torley R, Trimble D, Wirakusumah AD (2000) 10,000 Years of explosive eruptions of Merapi Volcano, Central Java: archaeological and modern implications. J Volcanol Geoth Res 100:9-50

Newman S, Lowenstern JB (2002) VOLATILECALC: a silicate melt$\mathrm{H}_{2} \mathrm{O}-\mathrm{CO}_{2}$ solution model written in Visual Basic for excel. Comput Geosci 28:597-604

Nielsen RL, Drake MJ (1979) Pyroxene-melt equilibria. Geochim Cosmochim Acta 43:1259-1272 
Nimis P (1995) A clinopyroxene geobarometer for basaltic systems based on crystal-structure modelling. Contrib Miner Petrol 121:115-125

Nimis P (1999) Clinopyroxene geobarometry of magmatic rocks. Part 2. Structural geobarometers for basic to acid, tholeiitic and mildly alkaline magmatic systems. Contrib Miner Petrol 135:62-74

Pallister JS, Schneider DJ, Griswold JP, Keeler RH, Burton WC, Noyles C, Newhall CG, Ratdomopurbo A (2013) Merapi 2010 eruption-chronology and extrusion rates monitored with satellite radar and used in eruption forecasting. J Volcanol Geoth Res 261:144-152

Papale P, Moretti R, Barbato D (2006) The compositional dependence of the saturation surface of $\mathrm{H}_{2} \mathrm{O}+\mathrm{CO}_{2}$ fluids in silicate melts. Chem Geol 229:78-95

Pichavant M (1981) An experimental study of the effect of boron on a water saturated haplogranite at $1 \mathrm{Kbar}$ vapour pressure. Contrib Miner Petrol 76:430-439

Portnyagin M, Almeev R, Matveev S, Holtz F (2008) Experimental evidence for rapid water exchange between melt inclusions in olivine and host magma. Earth Planet Sci Lett 272:541-552

Preece KJ (2014) Transitions between effusive and explosive activity at Merapi volcano, Indonesia: a volcanological and petrological study of the 2006 and 2010 eruptions. Ph.D. Thesis. University of East Anglia, UK

Preece K, Barclay J, Gertisser R, Herd R (2011) Petrological evidence of magma storage, ascent and extrusion at Merapi volcano, Java, Indonesia. Geophys Res Abstr 13:EGU2011-10518

Preece K, Barclay J, Gertisser R, Herd RA (2013) Textural and micro-petrological variations in the eruptive products of the 2006 dome-forming eruption of Merapi volcano, Indonesia: implications for sub-surface processes. J Volcanol Geoth Res 261:98-120

Putirka KD (2008) Thermometers and barometers for volcanic systems. Rev Mineral Geochem 69:61-120

Putirka KD, Mikaelian H, Ryerson F, Shaw H (2003) New clinopyroxene-liquid thermobarometers for mafic, evolved, and volatile-bearing lava compositions, with applications to lavas from Tibet and the Snake River Plain, Idaho. Am Mineral 88:1542-1554

Ratdomopurbo A (1995) Etude sismologique du volcan Merapi et Formation du dome de 1994. PhD Thesis, Université Joseph Fourier, Grenoble, France

Ratdomopurbo A, Poupinet G (2000) An overview of the seismicity of Merapi volcano (Java, Indonesia), 1983-1994. J Volcanol Geoth Res 100:193-214

Ratdomopurbo A, Beauducel F, Subandriyo J, Agung Nandaka IGM, Newhall CG, Suharna Sayudi DS, Suparwaka H, Sunarta S (2013) Overview of the 2006 eruption of Mt. Merapi. J Volcanol Geoth Res 261:87-97

Reubi O, Blundy J, Varley NR (2013) Volatiles contents, degassing and crystallisation of intermediate magmas at Volcan de Colima, inferred from melt inclusions. Contrib Miner Petrol 165:1087-1106

Ridolfi F, Puerini M, Renzulli A, Menna M, Toulkeridis T (2008) The magmatic feeding system of El Reventador volcano (SubAndean zone, Ecuador) constrained by texture, mineralogy and thermobarometry of the 2002 erupted products. J Volcanol Geoth Res 176:94-106

Ruprecht P, Bachmann O (2010) Pre-eruptive reheating during magma mixing at Quizapu volcano and the implications for the explosiveness of silicic are volcanoes. Geology 38:919-922

Saepuloh A, Koike K, Omura M, Iguchi M, Setiawan A (2010) SARand gravity change-based characterization of the distribution pattern of pyroclastic flow deposits as Mt. Merapi during the past 10 years. Bull Volc 72:221-232
Scandone R, Cashman KV, Malone SD (2007) Magma supply, magma ascent and style of volcanic eruptions. Earth Planet Sci Lett 253:513-529

Schatz OJ, Dolejš D, Stix J, Williams-Jones AE, Layne GD (2004) Partitioning of boron among melt, brine and vapor in the system haplogranite- $\mathrm{H}_{2} \mathrm{O}-\mathrm{NaCl}$ at $800{ }^{\circ} \mathrm{C}$ and $100 \mathrm{MPa}$. Chem Geol 210:135-147

Schwarzkopf LM, Schmincke HU, Troll VR (2001) Pseudotachylite on impact marks of block surfaces in block-and-ash flows at Merapi volcano, Central Java, Indonesia. Int J Earth Sci 90:769-775

Self S, Gertisser R, Thordarson T, Rampino MR, Wolff JA (2004) Magma volume, volatile emissions, and stratospheric aerosols from the 1815 eruption of Tambora. Geophys Res Lett 31:L20608

Severs MJ, Azbej T, Thomas JB, Mandeville CW, Bodnar RJ (2007) Experimental determination of $\mathrm{H}_{2} \mathrm{O}$ loss from melt inclusions during laboratory heating: evidence from Raman spectroscopy. Chem Geol 237:358-371

Shinohara H (1994) Exsolution of immiscible vapor and liquid phases from a crystallizing silicate melt: implications for chlorine and metal transport. Geochim Cosmochim Acta 58:5215-5221

Signorelli S, Vaggelli G, Romano C (1999) Pre-eruptive volatile $\left(\mathrm{H}_{2} \mathrm{O}, \mathrm{F}, \mathrm{Cl}\right.$ and $\left.\mathrm{S}\right)$ contents of phonolitic magmas feeding the 3550-year old Avellino eruption from Vesuvius, southern Italy. J Volcanol Geoth Res 93:237-256

Smyth HR, Hall R, Hamilton J, Kinny P (2005) East Java: Cenozoic basins, volcanoes and ancient basement. In: Proceeding, Indonesian Petroleum Association, Thirteenth Annual Convention \& Exhibition, pp 251-266

Sparks RSJ (1997) Causes and consequences of pressurisation in lava dome eruptions. Earth Planet Sci Lett 150:177-198

Stalder R, Skogby H (2003) Hydrogen diffusion in natural and synthetic orthopyroxene. Phys Chem Miner 30:12-19

Stix J, Layne GD (1996) Gas saturation and evolution of volatile and light lithophile elements in the Bandelier magma chamber between two caldera-forming eruptions. J Geophys Res 101:25181-25196

Surono Jousset P, Pallister J, Boichu M, Buongiorno MF, Budisantoso A, Costa F, Andreastuti S, Prata F, Schneider D, Clarisse L, Humaida H, Sumarti S, Bignami C, Griswold J, Carn S, Oppenheimer C, Lavigne F (2012) The 2010 explosive eruption of Java's Merapi volcano-A ‘100-year' event. J Volcanol Geoth Res 241-242:121-135

Suzuki Y, Yasunda A, Hokanishi N, Kaneko T, Nakada S, Fujii T (2013) Syneruptive deep magma transfer and shallow remobilization during the 2011 eruption of Shinmoe-dake, Japan-Constraints from melt inclusions and phase equilibria experiments. J Volcanol Geoth Res 257:184-204

Toutain J-P, Sortino F, Baubron J-C, Richon P, Surono, Sumarti S, Nonell A (2009) Structure and CO2 budget of Merapi volcano during inter-eruptive periods. Bull Volc 71:815-826

Troll VR, Hilton DR, Jolis EM, Chadwick JP, Blythe LS, Deegan FM, Schwarzkopf LM, Zimmer M (2012) Crustal $\mathrm{CO}_{2}$ liberation during the 2006 eruption and earthquake events at Merapi volcano, Indonesia. Geophys Res Lett 39:L11302

Troll VR, Deegan FM, Jolis EM, Harris C, Chadwick JP, Gertisser R, Schwarzkopf LM, Borisova AY, Bindeman IN, Sumarti S, Preece K (2013) Magmatic differentiation processes at Merapi volcano: inclusion petrology and oxygen isotopes. J Volcanol Geoth Res 261:38-49

van Bemmelen RW (1949) The geology of Indonesia, vol 1A, general geology. Government Printing Office, The Hague

Vigouroux N, Wallace PJ, Kent AJR (2008) Volatiles in high-K magmas from the western Trans-Mexican Volcanic Belt: evidence for fluid fluxing and extreme enrichment of the mantle wedge by subduction processes. J Petrol 49:1589-1618 
Villemant B, Boudon G (1998) Transition from dome-forming to plinian eruptive styles controlled by $\mathrm{H}_{2} \mathrm{O}$ and $\mathrm{Cl}$ degassing. Nature 392:65-69

Villemant B, Mouatt J, Michel A (2008) Andesitic magma degassing investigated through $\mathrm{H}_{2} \mathrm{O}$ vapour-melt partitioning of halogens at Soufrière Hills volcano, Montserrat, (Lesser Antilles). Earth Planet Sci Lett 269:212-229

Vlastélic I, Menard G, Gannoun A, Piro J-L, Staudacher T, Famin V (2013) Magma degassing during the April 2007 collapse of Piton de la Fournaise: the record of semi-volatile trace elements $(\mathrm{Li}$, B, Cu, In, Sn, Cd, Re, Tl, Bi). J Volcanol Geoth Res 254:94-107

Voight B, Constantine EK, Siswowidjoyo S, Torley R (2000) Historical eruptions of Merapi volcano, Central Java, Indonesia, 17681998. J Volcanol Geoth Res 100:69-138

Walter TR, Wang R, Zimmer M, Grosser H, Luehr B, Ratdomopurbo A (2007) Volcanic activity influenced by tectonic earthquakes: static and dynamic stress triggering at Mt, Merapi. Geophys Res Lett 34:L05304

Webster JD (1997) Chloride solubility in felsic melts and the role of chloride in magmatic degassing. J Petrol 38:1793-1807

Webster JD (2004) The exsolution of magmatic hydrosaline chloride liquids. Chem Geol 210:33-48

Webster JD, Holloway JR, Hervig RL (1989) Partitioning of lithophile trace elements between topaz rhyolite melt and $\mathrm{H}_{2} \mathrm{O}$ and $\mathrm{H}_{2} \mathrm{O}+\mathrm{CO}_{2}$ fluids. Econ Geol 84:116-134
Webster JD, Mandeville CW, Goldoff B, Coombs ML, Tappen C (2010) Augustine volcano-the influence of volatile components in magmas erupted A.D. 2006 to 2,100 years before present. In: Power JA, Coombs ML, Freymueller JT (eds) The 2006 eruption of Augustine volcano, Alaska. US Geol Surv Prof Pap 1769, pp 383-423

Wilson L, Sparks RSJ, Walker GPL (1980) Explosive volcanic eruptions-IV. The control of magma properties and conduit geometry on eruption column behaviour. Geophys J R Astron Soc 63:117-148

Wolf KJ, Eichelberger JC (1997) Syneruptive mixing, degassing, and crystallization at Redoubt Volcano, eruption of December, 1989 to May 1990. J Volcanol Geoth Res 75:19-37

Woods AW, Koyaguchi T (1994) Transitions between explosive and effusive eruptions of silicic magmas. Nature 370:641-644

Wright HM, Bacon CR, Vazquez JA, Sisson TW (2012) Sixty thousand years of magmatic volatile history before the calderaforming eruption of Mount Mazama, Crater Lake, Oregon. Contrib Miner Petrol 164:1027-1106

Zhang Y, Stolper EM, Wasserburg GJ (1991) Diffusion of water in rhyolitic glasses. Geochim Cosmochim Acta 55:441-456

Zimmer M, Erzinger J (2003) Continuous $\mathrm{H}_{2} \mathrm{O}, \mathrm{CO}_{2},{ }^{222} \mathrm{Rn}$ and temperature measurements on Merapi Volcano, Indonesia. J Volcanol Geoth Res 125:25-38 